\title{
Preconception care: delivery strategies and packages for care
}

\author{
Zohra S Lassi, Sohni V Dean, Dania Mallick, Zulfiqar A Bhutta*
}

\begin{abstract}
The notion of preconception care aims to target the existing risks before pregnancy, whereby resources may be used to improve reproductive health and optimize knowledge before conceiving. The preconception period provides an opportunity to intervene earlier to optimize the health of potential mothers (and fathers) and to prevent harmful exposures from affecting the developing fetus. These interventions include birth spacing and preventing teenage pregnancy, promotion of contraceptive use, optimization of weight and micronutrient status, prevention and management of infectious diseases, and screening for and managing chronic conditions. Given existing interventions and the need to organize services to optimize delivery of care in a logical and effective manner, interventions are frequently co-packaged or bundled together. This paper highlights packages of preconception interventions that can be combined and co-delivered to women through various delivery channels and provides a logical framework for development of such packages in varying contexts.
\end{abstract}

\section{Introduction}

Given the extent of the burden of maternal, newborn and child mortality; maternal, newborn and child health $(\mathrm{MNCH})$ interventions can be grouped together into package as part of continuum of care. This approach includes integrated service delivery for mothers and children from pregnancy to delivery, extending into the immediate postnatal period, and childhood. The $\mathrm{MNCH}$ continuum of care approach was introduced on the grounds that the health and well-being of women, newborns, and children are closely linked and should be managed in a unified way [1]. Moreover, delivering interventions in the form of packages promote greater efficiency by maximizing synergies and avoiding duplication of services compared to when delivered alone [2]. However, even with increased prenatal and postnatal care practices, there was a slow improvement in birth outcomes and this led to the realization that prenatal care might be a step too late for pregnant mothers. Thus, the targeted $\mathrm{MNCH}$ momentum was expanded to include reproductive health as an essential component. The recent Lancet neonatal series reviewed 39 preconception and antenatal interventions, of which only two were targeted interventions for the preconception period [3]. The review further suggested six packages

\footnotetext{
* Correspondence: zulfiqar.bhutta@aku.edu

Division of Women and Child Health, Aga Khan University Karachi, Pakistan
}

along the continuum of care for 75 countdown countries of which only one package included interventions for preconception period [3]. The package included interventions directed at improving nutritional status through balanced energy protein supplementation, folic acid supplementation/fortification, and micronutrient supplementation. Correcting nutritional status before pregnancy is important but changing the dynamics of maternal, neonatal and child health indices require holistic approach. Interventions to prevent and treat infection, chronic diseases, mental health and awareness of reproductive health are crucial elements and should also be targeted before pregnancy for ensuring improved pregnancy, neonatal and child health outcomes.

Therefore, the notion of preconception care aims to target the existing risks before pregnancy, whereby resources may be used to improve reproductive health of women, men and couples in order to optimize health and knowledge before conceiving a pregnancy. More recently, greater attention is being paid to the period before pregnancy, specifically focusing on preconception care. The preconception period provides an opportunity to intervene earlier to optimize the health of potential mothers (and fathers) and to prevent harmful exposures from affecting the developing foetus. These interventions include birth spacing and prevention of teenage pregnancy as young mothers often are not physically mature enough to deliver 
a baby, leaving them and their children at risk for death or disability from obstructed labor, fistulas, premature birth, or low birth weight. At the same time, early childbearing negatively affects educational and economic opportunities; women with lower educational attainment have greater risks of adverse pregnancy outcomes, are less knowledgeable about health-prevention activities, and family planning. Their children have fewer options for education, optimal growth and development and have a higher risk of mortality.

Preconception care is the provision of biomedical, behavioral and social health interventions to women and couples before conception occurs, aimed at improving their health status, and reducing behaviours and individual and environmental factors that could contribute to poor maternal and child health outcomes [4]. Its ultimate aim is improved maternal and child health outcomes, in both the short and long term. For the purpose of this review, preconception care and its boundaries were defined as: "any preventive, promotive or curative health care intervention provided to women of childbearing age in the period before pregnancy (at least 2 years) or between consecutive pregnancies, to improve health related outcomes for women (regardless of their pregnancy status), newborns or children up to 5 years of age" [5].

This paper summarizes key preconception risks and interventions which impact maternal, fetal, neonatal and child health outcomes (Refer to Paper 1-6), and proposes packages of evidence-based effective interventions for improved reproductive health and pregnancy outcomes. The paper also proposes strategies for delivery for such packages in varying contexts.

\section{Proposed packages of care}

We identified and recommended various interventions through systematic reviews [6-11] and evidence synthesis that are summarized in Table 1 according to the level of care at which each can be provided.

These interventions can also be bundled together and delivered in various packages to increase efficiency and give a synergistic effect. Figure 1 illustrates different packages that can be delivered through various delivery platforms. It is important to highlight that individual interventions included in these packages can be modified according to local context, priorities as well as feasibility of delivery within particular levels of the health and education systems. To illustrate, these interventions can be bundled into the following five packages for delivery.

1. Completion of secondary education for adolescent girls and prevention of teenage pregnancy

2. Nutritional counselling and family planning

3. Nutritional optimization and weight loss programs

4. Multicomponent youth development programs including infection prevention

5. Screening and management of chronic diseases including mental health

\section{Completion of secondary education for adolescent girls and prevention of teenage pregnancy}

To prevent teenage pregnancy and improve preconception care this package proposes comprehensive counselling, education and life skills development. Published papers highlighted the evidence regarding the adverse effects of teenage pregnancy on maternal and neonatal outcomes [12-15]. School-based prevention programs underscored the importance of the intervention by

Table 1 Preconception interventions and their delivery according to the level of care

\begin{tabular}{|c|c|c|c|}
\hline \multirow[t]{2}{*}{ Interventions } & \multicolumn{3}{|l|}{ Level of care } \\
\hline & Community & Primary & Referral \\
\hline \multicolumn{4}{|l|}{ Promoting Reproductive health } \\
\hline Promoting adolescent health & $\checkmark$ & $\checkmark$ & \\
\hline Preventing first and repeat pregnancy in adolescence & $\checkmark$ & $\checkmark$ & \\
\hline Birth spacing & $\checkmark$ & $\checkmark$ & $\checkmark$ \\
\hline Reproductive planning after abortion & & & $\checkmark$ \\
\hline Advanced maternal age & $\checkmark$ & $\checkmark$ & \\
\hline Genetic counselling & & $\checkmark$ & $\checkmark$ \\
\hline \multicolumn{4}{|l|}{ Nutritional status and supplementation } \\
\hline Maternal pre-pregnancy weight & $\checkmark$ & $\checkmark$ & \\
\hline Diet, exercise and weight loss & $\checkmark$ & $\checkmark$ & $\checkmark$ \\
\hline Folic acid supplementation & $\checkmark$ & $\checkmark$ & \\
\hline Multivitamins supplementation & $\checkmark$ & $\checkmark$ & \\
\hline Iron supplementation & $\checkmark$ & $\checkmark$ & \\
\hline \multicolumn{4}{|l|}{ Preventing and treating infections } \\
\hline Sexually transmitted infections & $\checkmark$ & $\checkmark$ & $\checkmark$ \\
\hline
\end{tabular}


Table 1 Preconception interventions and their delivery according to the level of care (Continued)

\begin{tabular}{lll}
\hline HIV/AIDS prevention strategies & $\checkmark$ & $\checkmark$ \\
\hline Vaccine usage & $\checkmark$ & $\checkmark$ \\
\hline Periodontal disease and dental caries & $\checkmark$ & $\checkmark$ \\
\hline Cytomegalovirus & $\checkmark$ & $\checkmark$ \\
\hline Screening and management of chronic diseases & $\checkmark$ \\
\hline Diabetes & $\checkmark$ \\
\hline Epilepsy management & $\checkmark$ \\
\hline Management of Phenylketonuria & $\checkmark$ \\
\hline Thyroid disorders & $\checkmark$ \\
\hline Systemic Lupus Erythromatoses and other connective tissue diseases & $\checkmark$ \\
\hline Medication use & $\checkmark$ \\
\hline Mental health & $\checkmark$ \\
\hline Intimate partner violence & $\checkmark$ & $\checkmark$ \\
\hline Substance abuse and lifestyle changes & $\checkmark$ \\
\hline Caffeine intake & $\checkmark$ & $\checkmark$ \\
\hline Alcohol intake & $\checkmark$ & $\checkmark$ \\
\hline Smoking cessation & $\checkmark$ & $\checkmark$ \\
\hline Illicit drugs consumption & $\checkmark$ & $\checkmark$ \\
\hline Ameliorating environmental exposures such as chemical and radiations & $\checkmark$ & $\checkmark$ \\
\hline
\end{tabular}

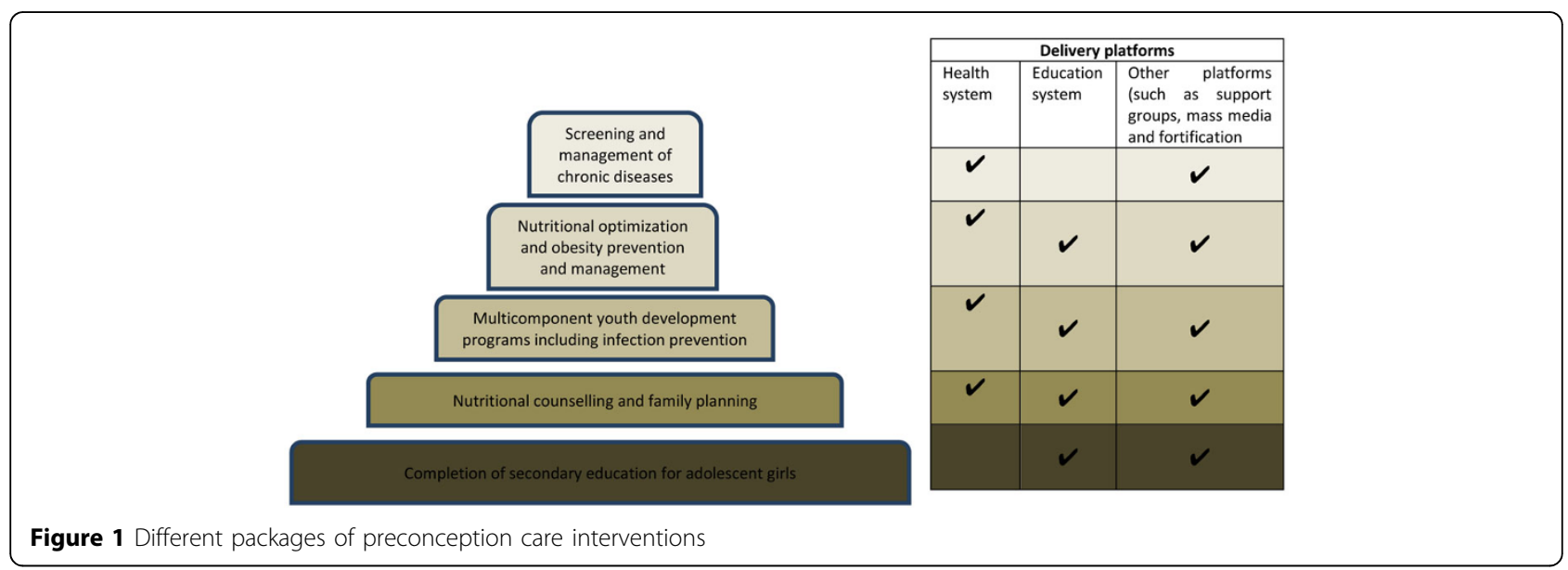

reducing psychological, physical and sexual dating violence [16-19], this was further confirmed in reviews which reported multi component programs reduce the assaults and incidence of domestic violence [7,20,21]. Considering these evidence, preconception counseling should be made available especially in schools, community centers, and adolescent health centers. These facilities can provide a space where sexually active young men and women know the risks of teen pregnancy, understand the use of condoms as well as long-acting methods of contraception. Sexual education appears to be more effective if it is integrated with broader life skills and education programs, including vocational abilities, effective communication, responsible decision making, proactive approach to personal health care and an increased awareness of health related issues. Since academic failure and teenage pregnancies are seen to be so closely interlinked, a special emphasis should be made to ensure that teenage girls complete a basic secondary education which will include educating young minds on preventing teenage pregnancies. The purpose of education is to develop the knowledge to observe, understand, reason and make rational judgment about the known realities of the world for optimum survival. Teens that have dropped out of high school are more likely to become pregnant, and their children are more likely to be deficient in terms of child 
development milestones such as language, communication, and cognition [22]. This has long-term implications for them as individuals, their families and communities [23]. Analysing the key issues in a community may help to identify what or who are the major contributors; for example service and health care providers may not be offering adequate counselling, sexual health information or contraceptive methods, or school systems may be deficient in providing a comprehensive sexual health class or may have failed to provide a safe environment where teens may discuss their problems. In short, adolescent sexual and reproductive health programs should include counselling, reproductive planning and contraception, and screening and management of sexually transmitted infections (STIs). On the other hand, girls in marginalized areas can be provided with preconception counseling in community settings by community health workers and outreach workers [7].

A teenager's biggest asset is knowledge. Education is the gradient process of acquiring knowledge. Knowledge gives a teenager the tools for rational reasoning and judgment. Knowledge helps a teen make better choices. Knowledge gives you options. The more knowledge a teen has, the more opportunities a teenager will have for making money. It is, therefore, important to underscore the benefits of completing secondary education among adolescents.

\section{Family planning and nutrition counselling}

Nutrition plays a paramount role in supporting the future pregnancy. Nutritional counselling of women prior to conception receives less importance compared to nutritional counselling of pregnant women; however if family planning and reproductive health services took a more integrated approach and included nutritional counselling - this could improve coverage. Preconception counselling will allow women at higher risks of malnutrition, such as older women (older than 35), teenage girls with restricted diets, or malnourished women with vitamin deficiencies, to be highlighted before conception so that appropriate action may be taken. Adolescents typically consume a diet that does not satisfy the required intake of iron, folate, or vitamin B6 and have high chances of being anaemic. Thus an integrated approach should be applied wherein couples who come in for family planning services may be targeted for nutrition counselling since they are at a preconception stage where they are looking to plan a future family and thus would want to adopt the best practices and habits to do so. In low and middle income countries (LMICs) and in marginalized parts of high income countries (HICs) where food insecurity is an issue, community programs to grow food or buy it collectively should be incorporated into nutritional programs.

Pre-conception counselling There is evidence that preconception counselling changes risk behaviours and results in improved maternal and neonatal outcomes
[24-43]. This includes risk assessment and counselling of women over the age of 35 on the increased risks associated with advanced maternal age [44-83], as well as genetic counselling of couples in a consanguineous marriage to ensure a healthy fetal outcome [84-88]. A closer look is taken into past obstetrical and gynecological history, past medical and drug history, chronic illnesses, family history of genetic disease and psychosocial history to rule out any potential complications of pregnancy. However, further randomized controlled trials are needed to show how preconception care affects maternal, newborn and child health (MNCH) outcomes, and to delineate where and by whom such care should be provided, how long before conception such care should begin, and which interventions are most successful.

Periconceptional folic acid supplementation Folic acid supplementation is known to reduce the risk of neural tube defects (NTDs) in the newborn [89-93]. Many women are still unaware of how much their nutritional status impacts their pregnancy outcomes, and improving women's nutritional behaviours should therefore begin during their earlier reproductive years. Women wishing to conceive should take 400ug of folic acid three months prior to pregnancy [94]. Women who have previously given birth to an infant with a NTD require higher levels of folic acid supplementation $(800 \mu \mathrm{g})$. Providers should assess women's dietary habits and discuss the importance of micronutrients as part of routine preconception counseling. Other nutrition-specific interventions (iron, calcium, balanced protein energy supplementation etc.) have only been studied in pregnant women, or if they have been studied during the preconception period the outcomes are limited to changes in biochemical markers while pregnancy and birth outcomes were not assessed [95-100].

Family planning One of the reasons for the slow progress towards millennium development goal (MDG)-5 is the inadequate delivery of family planning interventions, resulting in unintended pregnancies, subsequent abortions, and a subsequent rise in maternal mortality. A recent report demonstrated a high unmet need for family planning in countries like Mali and Chad with the lowest contraceptive prevalence rates [101]. The evidence showed an impact of long (>60 months) and short inter-pregnancy intervals (IPIs) ( $<6$ months) on preterm births, low birth weight and small for gestational age babies [102-122]. The evidence suggests that counselling can help women understand the possible risks to themselves and their children of very short and very long IPIs, and the risks of having an unintended pregnancy and unsafe abortion [123]. Women should be advised to wait 18-24 months after pregnancies ending in a live birth, and at least 6 months after an abortion, before conceiving again, and should be provided with appropriate contraceptive counselling. 


\section{Nutritional optimization and obesity prevention and management}

Evidence has showed that pre-pregnancy underweight and overweight are risk factors for an array of composite adverse pregnancy and neonatal outcomes [63,124-155]. It is suggested that pre-pregnancy body mass index (BMI) should be maintained within the normal range of $18.5-24.9 \mathrm{~kg} / \mathrm{m}^{2}$ and controlled via diet and exercise modifications (Refer to Paper 3[8]). The interventions for healthy diet and exercise should be encouraged from late childhood and early adolescent years to be effective [156-166]. Routine preconception care with regards to weight should include calculating BMI for women of reproductive age, increasing awareness regarding the risks associated with being overweight or underweight, and helping women develop individualized dietary plans including consumption of a variety of healthy foods in appropriate amounts, and dietary supplements (especially a multivitamin containing $400 \mu \mathrm{g}$ of folic acid, calcium and vitamin D, and iron). Balanced protein energy supplementation and appropriate micronutrient supplementation can reduce the risk of outcomes related with pre-pregnancy underweight, especially in LMICs. All women should be encouraged to get their risks assessed for cardiovascular health with regards to weight bearing and offered appropriate lifestyle modifications. Women with high BMI's should be counselled to understand the risks of infertility that are a part of increased weight gain. A focus on screening, treating and preventing sexually transmitted infections (STIs) in the preconception period is vital, as well as educating parents about the risk of vertical transmission of such infections to the child.

\section{Multicomponent youth development programs including prevention of sexually transmitted infections}

Multicomponent youth development programs which encompass social, family, peer, community, educational and health disciplines are deigned to meet youth developmental needs and help them become healthy, happy and productive adults. Youth and particularly older children should be encouraged to take part in these programs. A proper and effective program will also help reduce problems such as substance abuse and teenage pregnancies [167-169]. Mentoring will be an essential component of these programs where developing youth are supported and encouraged to develop competencies, to take on leadership responsibilities, and to integrate into positive peer groups. By focusing on health and self-confidence issues, guidelines on how to eat healthy and reach desired BMI, as well as sexual health issues such as practicing safe sex and when and how to deal with STIs may be included. Programs that deal with alcohol or substance abuse as well as smoking cessation programs [29] can also be packaged into these multicomponent youth development programs to be highly effective [11].
Sexually Transmitted Infections The review of evidence highlighted the wide gaps in current knowledge regarding the effects of treatment of STIs in the preconception period on combined maternal and neonatal outcomes [170-172]. Evidence from intervention that delivered behavioural counselling showed reduction in re-infection and new incidence of STI, thus this can reduce transmission of infection to the newborn, as well as improve the health of the woman during pregnancy and in the first year after birth [173-175]. Preventive care can be implemented with the application of preconception care by raising awareness on STIs and their symptoms and prevention, cervical screening, and PAP smears. All women of childbearing age should undergo testing for STIs. It is, however, warranted that more studies be conducted regarding STI treatment and counselling in the preconception period on maternal behaviours and future maternal and neonatal outcomes [9].

HIV/AIDS prevention strategies All men and women should be encouraged to find out their HIV status before starting a family which can be a part of preconception counseling; if women test positive, they should be educated in detail of the risks of vertical transmission to the child and the risks for increased mortality and morbidity that is associated with this disease. Various strategies (e.g. prophylactic treatment of reproductive age women with antiretrovirals to prevent HIV transmission to her partner and newborn; condom use to prevent HIV transmission; counseling and voluntary testing to lower the risk of transmission through unprotected intercourse; and treatment of STIs for risk reduction) for preventing HIV/AIDS were reviewed [167,173,176-228]. Preconception care for women living with HIV/AIDS or HIV-positive partners is recommended. This should include effective and appropriate contraception to reduce the chance of unintended pregnancy, psychological and emotional support to encourage disclosure of sero-status to partner, education regarding the risks of perinatal transmission and strategies for prevention and screening, and treatment for STIs in partners [9].

\section{Screening and management of chronic diseases including mental health}

The evidence highlights the importance of women's health status including the presence of chronic diseases, current infections or syndromes, and promotes general screening and management for other chronic health related matters [229-264]. Another major component of health, which is mental health, is also highlighted as a package to reduce depression or anxiety disorders which may have adverse effects on the child's health [265,266]. On par with that, domestic violence will also have a negative impact on emotional health and mental wellbeing such as posttraumatic stress disorder or psychiatric issues with abuse or rape [267-315]. This package serves to 
highlight the importance of empowering women to take control of their own health issues, to report physical or sexual harassment and abuse, and to be proactive in matters concerning their own health by screening and testing for chronic infections before planning a pregnancy [10,316-328].

All women who are chronic carriers of a disease such as hepatitis $B$ should be counselled to receive vaccination if not done previously and instructed on how to prevent vertical transmission to future child or horizontal transmission to close contacts. Women with chronic health problems such as hypertension or hyper/hypothyroidism should be counselled about the risks associated with their disease during pregnancy, and the necessity to change medication regimens while pregnant or conceiving to optimize hormonal levels and to prevent any harm to the foetus. Management and counselling of diabetic women during the preconception period is more beneficial than during pregnancy $[329,330]$. Preconception care for women with pre-gestational diabetes should include education about the importance of strict glycaemic controls (with an HbA1C level of less than 6-7\%) to prevent congenital anomalies; teaching self-management skills with pre-set monitoring targets; counselling on the effect of poor glycaemic control on maternal complications and fetal complications; counselling about diet (as per protocol for diabetes); and healthy physical activity for weight management [10]. Testing to detect pre-diabetes or type2 diabetes should be a priority for high-risk women who are obese or overweight or those who have a strong family history of diabetes.

Maternal Mental health Mental health issues in mothers often remain undiagnosed and their management often overlooked. Evidence suggests linkages between poor adolescent mental health and poor pregnancy and postpartum outcomes [10,331-334]. Preconception care for psychiatric conditions is recommended; this should include screening of women in their childbearing years for mood disorders and identifying those at risk; counselling women with pre-existing depression and anxiety disorders about the potential risks of untreated illness and its associated negative health outcomes; and informing potential mothers about the risks and benefits of various treatment options prior to conception and during pregnancy. Women of reproductive age must be counselled that relapse might be a complication during pregnancy for bipolar disorder or schizophrenia patients since they will be discontinuing treatment. A relapse prevention and treatment strategy should be drawn out as part of a pre conception plan.

Prevention of domestic violence Domestic violence in females is a major contributor to ill health, particularly to their reproductive and sexual health, and it is also a violation of human rights which is mostly brought about due to gender inequality. A growing problem in both LMICs and HICs, physical abuse leads to negative outcomes such as injuries, trauma, unwanted pregnancies, and emotional disturbances [270,281,288,295,296,335]. In areas or societies where domestic violence is a common practice, females might not have the autonomy of making decisions related to their reproductive health which leads to a higher risk of contracting sexually transmitted infections as well as unwanted pregnancies, or multiple pregnancies without adequate time to recover. Women who are subject to regular acts of violence may be victims of such abuse even during pregnancy, which has deleterious effects on the foetus. General support groups may be able to reduce incidences of domestic violence or at least raise awareness among such females, and build a system where such women can feel safe reporting such incidences [10].

\section{Opportunities for delivery}

Interventions that are implemented in various settings particularly in low-income countries face the challenge of a lack of standardization across the line of service delivery, community outreach, and organizational policies. Each setting has different requirements, which might bring about healthcare inequities, but can be substantially reduced by integrating intervention packages into existing local health programs. To ensure sustainability and to be as efficient as possible at meeting health care outcomes, the measure of integration with existing health care systems and within other delivery platform is vital; not only will it help in overcoming barriers to service delivery and accessibility, but output delivery can be amplified. As a result, existing systems are strengthened and improved further, sparking positive development in the form of viable healthcare networks in such communities. To ensure that the packages of care that have been a product of much research and knowledge are translated into action, the following opportunities for delivery and integrating services within the broader platform can provide a means to do so.

\section{a) Delivery within the education system} School health and reproductive health education programs Information and services must be made available to adolescents to educate them on their sexuality and protect themselves from unwanted pregnancies, STIs, or risks of infertility. School-wide accepted sexed programs have shown to delay the onset of sexual activity and increase safer sexual practices by those that are already sexually active. All females should be counselled through regular school health programs about eating disorders, such as anorexia or bulimia and the risks to fertility and future pregnancies it might have. The reproductive and sexual health program should be integrated as a vital component 
of the school curricula and must be tested upon to emphasize its importance. Adolescents should be guided as to how to make responsible decisions concerning their sexual lives, as well as how to practice safe sex, and how to prevent unwanted pregnancies.

\section{b) Delivery within health system}

\section{Primary-level health workers (e.g. community health workers)}

The primary level health workers are the backbone to the whole establishment of primary health care. By delivering health services to the doorsteps of the community as in the case of community health workers (CHWs), concepts such as family planning, vaccinations or immunizations, proper growth monitoring, nutrition for neonates and control of common diseases can be implemented. CHWs can be trained to offer guidance and increase awareness regarding STIs, to assess maternal health and nutrition status in order to improve postpartum outcomes. They can also provide information about all forms of contraceptives, their benefits and efficacy and also provide information on emergency contraception to the female population of child bearing age in a community. Folic acid, iron and micronutrient supplementations may also be distributed in this way along with a basic orientation of the importance of such supplements to improve maternal and child health. Health education that is a vital part of preconception care and health promotion, but which may be impractical to distribute effectively in most clinical settings, especially in busy health clinics with large patient to doctor ratios can utilize $\mathrm{CHWs}$ to increase awareness levels.

\section{Pre-marital counseling and screening}

Pre-marital counselling and screening allows couples to test for the presence of infectious diseases such as HIV/ AIDS, Hepatitis B and C, syphilis or for genetic diseases such as beta-thalassemia or sickle cell haemoglobinopathies in both male and female to ensure proper care is taken before a pregnancy is planned. Such services should be available at all clinics/outreach clinics and doctors should make patients aware that this is a necessary and important step to take before starting a family. Regular screening should be conducted in high risk families by testing them and having them sit down with a geneticist and receive counselling on the best course of action. This would greatly reduce the occurrence of hereditary disorders.

\section{Expanded post-natal care}

During the first days to weeks after birth, the postnatal period is the ideal time to deliver interventions to improve the health and survival of both the newborn and the mother, a facility that a majority of mothers currently avail. However, an efficient strategy would be to expand post-natal care to include preconception care as well to optimize chances of a healthy conception, pregnancy and delivery. Programs should also aim to provide earlier and more integrated care as a majority of pregnancy complications may be avoided with proper screening, personal history, nutritional counseling, and genetic counseling so parents can be better equipped to handle a pregnancy and subsequent birth.

\section{Take advantage of other health visits and missed opportunities}

For most patients coming in for regular check-ups to a general physician in walk-in clinics, emergency department and sports medicine clinics must take an accurate and detailed history complete with relevant tests and refer to a specialist when needed. The doctor can also offer basic care and guidance regarding reproductive health to patients to improve maternal, neonatal and child health.

\section{Add preconception-related items to provider checklists}

Integrate essential components of nutrition such as folic acid, iron, zinc, and micronutrient supplementation alongside programs that have a high coverage such as vaccination or immunization programs which could target both pregnant women as well as neonates.

\section{c) Other platforms}

\section{Community support groups}

Community-based programs that provide pre-conception services will cater directly to the specific needs of the particular community. Instead of a larger scale system of preconception care, support groups will be able to distribute care into smaller communities, villages, and rural areas. Members of support groups are usually facing similar issues and can benefit greatly from the shared experiences, advice and health support of the other participants. Key issues of the community such as a high rate of teenage pregnancies or poor family planning services can also be targeted and interventions can then be tailored and implemented accordingly. For example, through support group sessions, teenage girls can be taught confidence and empowerment skills to contest early or forceful marriages; they can also be taught some sort of self defence mechanism if rape and unwanted sexual advances are an issue.

\section{Mass media campaigns/ Social marketing}

Modern marketing techniques and social communications have been successfully used in many regions to promote the importance of reproductive health. Many of the interventions can be delivered through health facilities but to reach a larger audience mass mobile text messages or radio announcements may also be used where applicable. Mass campaigns regarding immunization programs in a locality or on the importance of family planning and availability of family planning clinics in different areas may be advertised on TV channels, radio programs or through text messages. Mass media campaigns for TV, radio and print media may 
be utilized to promote safer sexual practices, especially using condoms to prevent STIs. Local celebrities or personas may be used to promote a healthy image of utilizing pre-conception care at local health facilities. A challenge faced by many at-risk young adults in developing countries is the fact that most of them are illiterate, or have poor exposure to educational programs - mass media may be a very useful tool for effectively transmitting basic health messages to such a population. It can also be an instrument for changing behavioural stereotypes, pre-formed attitudes, myths and misconceptions regarding reproductive health

\section{Workplace programs or referrals}

Educational workshops may be conducted that are mandatory in workplace venues where men and women both need to attend sessions on sexual health/STI's, smoking cessation, and other health-related topics. By providing access to sexual rehabilitation programs for employees and their spouses, which would include coping mechanisms for infertility, menopause, late pregnancies, miscarriages, or pregnancy complications, a significant reduction in risky sexual behaviors and practices as well as distress resulting from infertility or other issues may be achieved. A high prevalence of sexual problems with age may be secondary to other medical conditions which must be investigated; when left untreated, these problems will lead to a decreased quality of life, depression, peer and spouse conflicts.

\section{Food fortification}

Food fortification is the practice of adding micronutrients to processed foods for an increase in the micronutrient status of a population and a decrease in deficiencies and related programs. A very cost-effective program, the addition of folic acid to enrich flour, rice and pasta takes advantage of existing technologies and local distribution networks.

\section{Support groups for individuals with a particular risk}

Support groups for high-risk couples and women, including those who have experienced a previous poor outcome. Such programs provide outreach, case management, risk reduction, support, prenatal/preconception care, health education and community development to high-risk women and couples. Such women and couples who have had a previous miscarriage, delivery of a low birth weight (LBW) infant, lack of family planning, repeated STI's, early pregnancies, substance abuse, and lack of access to reproductive health care would be the target group for maximum benefit. The individual's case would be assessed and a goal plan drawn out involving the patient at every step; from here on, the support group staff ensures compliance with services and keeps updated with the achievement of personal goals.

\section{Discussion}

This paper has highlighted the inextricable link between maternal and newborn health by providing evidence of the effect of interventions delivered during the preconception period on maternal and neonatal outcomes. Only a few systematic efforts have identified potential synergies between key reproductive health interventions on maternal and perinatal outcomes. This paper identified papers that underscored these synergies and illustrated a number of important interventions that should be delivered during the preconception period. Most of the interventions reviewed will require additional high quality evidence before recommendation for their implementation in programs.

Considering the interdependent relationship between maternal and neonatal health, approaching interventions that have a direct effect on $\mathrm{MNCH}$ services has great potential for accelerating progress towards MDG 4 and 5. The integration of these interventions needs to span not only in time period (pregnancy, childbirth, and the postnatal period) but also levels of care (household, community, and health facilities). The delivery of these interventions can have profound translational and intergenerational impacts with important implications for the long-term well-being of both mother and newborn. This can also promote greater efficiency by maximizing synergies and avoiding duplication of services that are less efficient if delivered individually. Therefore, these interventions should be integrated in health policies and programs. Such potential integration of strategies would not only help improve maternal and newborn outcomes but would also save scarce resources. This approach is critical to achieving MDGs 4 and 5 and making sure that we progress beyond saving lives to also improving morbidities and other developmental outcomes.

At the present time, preconception care is not implemented at a global level, and is not a widespread concept in LMICs as of yet. These packages feature intervention packages, opportunities for delivery and highlight the implementation of intervention packages via existing health care and public health programs. An emphasis is placed on the importance of expanding already existing programs such as antenatal care to include preconception care which would be an effective strategy in low-income countries and would capture a wide audience. To implement on a community level, an understanding and awareness should be developed for all stakeholders so that healthcare providers as well as higher policy makers may reach a shared consensus. A shared goal and a quantifiable and easily measured objective must be drawn out such as a reduction in maternal and infant mortality by a predetermined date in time or a significant decrease in maternal and neonatal infections for example. Organizations who propose to forward the preconception care packages and health care providers, as well as primary level health care workers such as community health workers should develop an agenda for goals, objectives, action plans, and 
evaluation strategies. Those organizations that have prior experience in delivering preconception care could be invited to give an expert opinion in what approaches are effective or what errors may be avoided.

Since malnutrition and vitamin and nutrient deficiencies contribute globally to a huge burden of disease processes, from LMICs to HICs, packages focused on supplementation strategies such as folic acid or micronutrient supplementation, and fortification of foods should be implemented on a national level with strict guidelines and limitations. Iodine, iron, vitamin $\mathrm{A}$, and zinc were identified being among the world's most serious health risk factors leading not only to clinical manifestations such as anaemia or metabolism disorders but also contributing to delayed motor and cognitive development. Food fortification, when implemented on a national level, with effective policies to govern safe practices, will be able to target a large segment of the population. In countries where vitamin D levels has been tested and known to be deficient in over $90 \%$ of the population, vitamin D fortified milk should be made available at all places. Where the level of deficiencies are too high such as populations where anaemia rates are endemic, then accessibility of the fortified foods to poorer settlements must be taken into concern or the presence of existing infections must be evaluated since it will raise the metabolic requirement for the micronutrient.

Multi-component youth development programs, sexual education programs, and community support groups as packages should be targeted to empower women and girls to take control of their own health especially reproductive health, to make responsible and autonomous decisions regarding their sexual life, to prevent or report domestic violence, and to prevent sexually transmitted infections by being firm on the use of contraceptives. This can be implemented at the community level with regards to specific issues of each community such as a high rate of rape cases may be countered with increased awareness and availability of emergency contraception and promotion of self-defence.

Other packages such as nutritional counselling, genetic counselling, and pre-marital screening should be targeted to involve both male and females as a couple and the focus should be on the health and wellbeing of the future family including parents and the child. Other packages such as family planning or contraceptive methods should take a multi-centred approach with delivery through various forums such as awareness through workshops and community support groups, provision of subsidized condoms in a poor community, advocating the benefits and warning of the risks of infections through health care facilities.

For implementation in LMICs at a community and facility level, cultural and social diversities and customs must be taken into account. Many regions and areas have deeply embedded social norms and traditions that govern their people's beliefs and actions; an example would be of religious barriers to contraceptive methods practiced in a majority of rural or low income communities especially in South East Asia. This would provide a significant barrier to preconception care packages such as family planning packages, which rely on effective contraceptive practices, or packages that advocate the use of condoms to prevent STIs. CHWs can be directed to raise awareness levels in such communities while delivering packages as doorsteps as well as conducting community level workshops.

Once a shared consensus of the aims and objectives are drawn out, all stakeholders must be engaged from the community to the national level; those organizations such as non-profit organizations which are working on a sole purpose such as reducing HIV/AIDS prevalence may be incorporated into this wider program and be used to reach a larger target audience. Rehabilitation centres for substance abuse, smoking cessation clinics, and other outlets may be utilized as well to bring about a combined preconception package to a much larger segment of the population. Areas where these packages may not be reaching such as prisons or homeless shelters for example must have a specified implementation package as well to ensure as large a distribution of preconception care as possible.

\section{Conclusion}

Since reducing maternal and child mortality and morbidity rates are of utmost and urgent concern in LMICs and more specifically in certain regions in these countries, then preconception care can address such populations with the appropriate packages of care. To achieve that significant reduction in maternal and child mortality rates, existing care that includes pregnancy care, as well as antenatal care should be extended to include preconception care as well as take into account adolescents, women of child-bearing age, and all high risk women. A focus on prevention of infections or deleterious habits, which will eventually become complications during pregnancy and a primary focus on improving reproductive health, will be the cornerstones of the implementations of these packages.

\section{Peer review}

Peer review files are included in additional file 1.

\section{Additional material}

Additional file 1: Peer review reports

Competing interests

We do not have any financial or non-financial competing interests for this review. 


\section{Acknowledgment}

The publication of these papers and supplement was supported by an unrestricted grant from The Partnership for Maternal, Newborn and Child Health.

\section{Declarations}

This article has been published as part of Reproductive Health Volume 11 Supplement 2, 2014: Preconception interventions. The full contents of the supplement are available online at http://www.reproductive-health-journal. com/supplements/11/S3. Publication charges for this collection were funded by the Partnership for Maternal, Newborn \& Child Health (PMNCH).

Published: 26 September 2014

\section{References}

1. Kerber KJ, de Graft-Johnson JE, Bhutta ZA, Okong P, Starrs A, Lawn JE: Continuum of care for maternal, newborn, and child health: from slogan to service delivery. Lancet 2007, 370(59595):1358-1369.

2. Darmstadt GL, Bhutta ZA, Cousens S, Adam T, Walker N, de-Bernis L: Evidence-based, cost effective interventions: how many newborn babies can we save? Lancet 2005, 365(9463):977-988.

3. Bhutta ZA, Das JK, Bahl R, Lawn JE, Salam RA, Paul VK, Sankar JM, Blencowe $\mathrm{H}$, Rizvi $\mathrm{A}$, Chou VB, et al: Can available interventions end preventable deaths in mothers, newborn babies, and stillbirths, and at what cost? Lancet 2014, pii: S0140-6736(14)60792-3. doi: 10.1016/S01406736(14)60792-3. [Epub ahead of print].

4. Meeting to Develop a Global Consensus on Preconception Care to Reduce Maternal and Childhood Mortality and Morbidity [http://apps. who.int/iris/bitstream/10665/78067/1/9789241505000_eng.pdf]. 2012.

5. Bhutta Z, Dean S, Imam A, Lassi Z: A Systematic Review of Preconception Risks and Interventions. Karachi. The Aga Khan University; 2011.

6. Dean SV, Lassi ZS, Imam AM, Bhutta ZA: Preconception Care: closing the gap in the continuum of care to accelerate improvements in maternal, newborn and child health. Reproductive Health 2014.

7. Dean SV, Lassi ZS, Imam AM, Bhutta ZA: Preconception care: promoting reproductive planning. Reproductive Health 2014.

8. Dean SV, Lassi ZS, Imam AM, Bhutta ZA: Preconception care: nutritional risks and interventions. Reproductive Health 2014.

9. Lassi ZS, Imam AM, Dean SV, Bhutta ZA: Preconception Care: preventing and treating infections. Reproductive Health 2014.

10. LAssi ZS, Imam AM, Dean SV, Bhutta ZA: Preconception Care: screening and management of chronic disease and promoting psychological health. Reproductive Health 2014.

11. Lassi ZS, Imam AM, Dean SV, Bhutta ZA: Preconception care: caffeine, smoking, alcohol, drugs and other environmental chemical/radiation exposure. Reproductive Health 2014

12. WHO: Adolescent pregnancy -Unmet needs and undone deeds. 2007.

13. Paranjothy $S$, Broughton $H$, Adappa R, Fone D: Teenage pregnancy: who suffers? Archives of disease in childhood 2009, 94(3):239.

14. Chen XK, Wen SW, Fleming N, Demissie K, Rhoads GG, Walker M: Teenage pregnancy and adverse birth outcomes: a large population based retrospective cohort study. International Journal of Epidemiology 2007

15. Gibbs CM, Wendt A, Peters S, Hogue CJ: The impact of early age at first childbirth on maternal and infant health. Paediatric and perinatal epidemiology 2012, 26(s1):259-284.

16. Foshee VA, Bauman KE, Arriaga XB, Helms RW, Koch GG, Linder GF: An evaluation of Safe Dates, an adolescent dating violence prevention program. American journal of public health 1998, 88(1):45

17. Foshee VA, Bauman KE, Greene WF, Koch GG, Linder GF, MacDougall JE: The Safe Dates program: 1-year follow-up results. American journal of public health 2000, 90(10):1619.

18. Foshee VA, Bauman KE, Ennett ST, Linder GF, Benefield T, Suchindran C: Assessing the long-term effects of the Safe Dates Program and a booster in preventing and reducing adolescent dating violence victimization and perpetration. American journal of public health 2004, 94(4):619.

19. Wolfe DA, Wekerle C, Scott K, Straatman AL, Grasley C, Reitzel-Jaffe D: Dating violence prevention with at-risk youth: a controlled outcome evaluation. Journal of Consulting and Clinical Psychology 2003, 71(2):279.

20. Hahn R, Fuqua-Whitley D, Wethington H, Lowy J, Liberman A, Crosby A, Fullilove M, Johnson R, Moscicki E, Price LS: The effectiveness of universal school-based programs for the prevention of violent and aggressive behavior. Morb Mortal Wkly Rep 2007, 56:1-12.

21. Anderson JL, Waller DK, Canfield MA, Shaw GM, Watkins ML, Werler MM: Maternal obesity, gestational diabetes, and central nervous system birth defects. Epidemiology 2005, 16(1):87.

22. Barlow J, S N, Bennett C, Huband N, Jones H, Coren E: Individual and group based parenting programmes for improving psychosocial outcomes for teenage parents and their children. Cochrane Database of Systematic Reviews 2011, 3, Art.No.: CD002964.

23. Harden A, Brunton G, Fletcher A, Oakley A: Teenage pregnancy and social disadvantage: systematic review integrating controlled trials and qualitative studies. BMJ 2009, 339:b4254.

24. Azad K, Barnett S, Banerjee B, Shaha S, Khan K, Rego AR, Barua S, Flatman D, Pagel C, Prost A: Effect of scaling up women's groups on birth outcomes in three rural districts in Bangladesh: a cluster-randomised controlled trial. The Lancet 2010, 375(9721):1193-1202.

25. Bhutta ZA, Soofi S, Cousens S, Mohammad S, Memon ZA, Ali I, Feroze A, Raza F, Khan A, Wall S: Improvement of perinatal and newborn care in rural Pakistan through community-based strategies: a clusterrandomised effectiveness trial. The Lancet 2011.

26. Manandhar DS, Osrin D, Shrestha BP, Mesko N, Morrison J, Tumbahangphe KM Tamang S, Thapa S, Shrestha D, Thapa B: Effect of a participatory intervention with women's groups on birth outcomes in Nepal: clusterrandomised controlled trial. The Lancet 2004, 364(9438):970-979.

27. Tripathy P, Nair N, Barnett S, Mahapatra R, Borghi J, Rath S, Gope R, Mahto D, Sinha R: Effect of a participatory intervention with women's groups on birth outcomes and maternal depression in Jharkhand and Orissa, India: a cluster-randomised controlled trial. The Lancet 2010, 375(9721):1182-1192.

28. Jack BW, Culpepper L, Babcock J, Kogan MD, Weismiller D: Addressing preconception risks identified at the time of a negative pregnancy test. A randomized trial. The Journal of family practice 1998, 47(1):33.

29. Elsinga J, de Jong-Potjer LC, van der Pal-de Bruin KM, le Cessie S, Assendelft WJJ, Buitendijk SE: The effect of preconception counselling on lifestyle and other behaviour before and during pregnancy. Women's Health Issues 2008, 18(6S):117-125.

30. de Jong-Potjer LC, Elsinga J, Le Cessie S, Van der Pal-de Bruin KM, Neven AK, Buitendijk SE, Assendelft WJJ: GP-initiated preconception counselling in a randomised controlled trial does not induce anxiety. BMC Family Practice 2006, 7(1):66.

31. Lumley J, Donohue L: Aiming to increase birth weight: a randomised trial of pre-pregnancy information, advice and counselling in inner-urban Melbourne. BMC Public Health 2006, 6(1):299.

32. Whitworth M, Dowswell T: Routine pre-pregnancy health promotion for improving pregnancy outcomes. Cochrane Database Syst Rev 2009, 4:CD007536.

33. Hillemeier MM, Downs DS, Feinberg ME, Weisman CS, Chuang CH, Parrott R, Velott D, Francis LA, Baker SA, Dyer AM: Improving women's preconceptional health findings from a randomized trial of the Strong Healthy Women intervention in the Central Pennsylvania women's health study. Women's Health Issues official publication of the Jacobs Institute of Women's Health 2008, 18(6 Suppl):S87.

34. Czeizel AE: Ten years of experience in periconceptional care. European Journal of Obstetrics \& Gynecology and Reproductive Biology 1999, 84(1):43-49.

35. Livingood WC, Brady C, Pierce K, Atrash H, Hou T, Bryant T: Impact of PreConception Health Care: Evaluation of a Social Determinants Focused Intervention. Maternal and child health journal 2010, 14(3):382-391.

36. Moos MK, Bangdiwala SI, Meibohm AR, Cefalo RC: The impact of a preconceptional health promotion program on intendedness of pregnancy. American Journal of Perinatology 1996, 13(2):103-108.

37. Midhet F, Becker S: Impact of community-based interventions on maternal and neonatal health indicators: Results from a community randomized trial in rural Balochistan, Pakistan. Reproductive Health 2010, 7(1):30.

38. O'Rourke K, Howard-Grabman L, Seoane G: Impact of community organization of women on perinatal outcomes in rural Bolivia. Revista Panamericana de Salud Pública 1998, 3:9-14

39. Colbourn T, Nambiar B, Bondo A, Makwenda C, Tsetekani E, Makonda-Ridley A, Msukwa M, Barker P, Kotagal U, Williams C: Effects of quality improvement in health facilities and community mobilization through women's groups on maternal, neonatal and perinatal mortality in three districts of Malawi: MaiKhanda, a cluster randomized controlled effectiveness trial. International Health 2013, 5(3):180-195. 
40. Lewycka S, Mwansambo C, Rosato M, Kazembe P, Phiri T, Mganga A, Chapota H, Kainja E, Newell M-L, Greco G: Effect of women's groups and volunteer peer counselling on rates of mortality, morbidity, and health behaviours in mothers and children in rural Malawi (MaiMwana): a factorial, cluster-randomised controlled trial. Lancet 2013, 381(9879):1721-1735.

41. More NS, Bapat U, Das S, Alcock G, Patil S, Porel M, Vaidya L, Fernandez A, Joshi W, Osrin D: Community mobilization in Mumbai slums to improve perinatal care and outcomes: a cluster randomized controlled trial. PLOS Med 2012, 9(7):e1001257.

42. Fottrell E, Azad K, Kuddus A, Younes L, Shaha S, Nahar T, Aumon BH, Hossen M, Beard J, Hossain T: The Effect of Increased Coverage of Participatory Women's Groups on Neonatal Mortality in Bangladesh: A Cluster Randomized Trial. JAMA Pediatrics 2013, 167(9):816-825.

43. Baqui AH, El-Arifeen S, Darmstadt GL, Ahmed S, Williams EK, Seraji HR, Mannan I, Rahman SM, Shah R, Saha SK: Effect of community-based newborn-care intervention package implemented through two servicedelivery strategies in Sylhet district, Bangladesh: a cluster-randomised controlled trial. Lancet 2008, 371(9628):1936-1944.

44. Abu Heija AT, Jallad MF, Abukteish F: Maternal and perinatal outcome of pregnancies after the age of 45. Journal of Obstetrics and Gynaecology Research 2000, 26(1):27-30

45. Astolfi P, Zonta LA: Delayed maternity and risk at delivery. Paediatric and perinatal epidemiology 2002, 16(1):67-72.

46. Astolfi $P$, De Pasquale A, Zonta L: Late childbearing and its impact on adverse pregnancy outcome: stillbirth, preterm delivery and low birth weight. Revue d'épidémiologie et de santé publique 2005, 53:97-105.

47. Bianco A, Stone J, Lynch L, Lapinski R, Berkowitz G, Berkowitz RL: Pregnancy outcome at age 40 and older. Obstetrics \& Gynecology 1996, 87(6):917-922

48. Canterino JC, Ananth CV, Smulian J, Harrigan JT, Vintzileos AM: Maternal age and risk of fetal death in singleton gestations: USA, 1995-2000. Journal of Maternal-Fetal and Neonatal Medicine 2004, 15(3):193-197.

49. Cnattingius R, Cnattingius S, Notzon FC: Obstacles to reducing cesarean rates in a low-cesarean setting: the effect of maternal age, height, and weight. Obstetrics \& Gynecology 1998, 92(4):501-506.

50. Conde-Agudelo A, Belizan JM: Risk factors for pre-eclampsia in a large cohort of Latin American and Caribbean women. BJOG 2000, 107(1):75-83.

51. Donoso E, Villarroel L: Reproductive risk of women over 40 years old]. Revista médica de Chile 2003, 131(1):55.

52. Feldman GB: Prospective risk of stillbirth. Obstetrics and gynecology 1992, 79(4):547.

53. Feresu SA, Harlow SD, Welch K, Gillespie BW: Incidence of stillbirth and perinatal mortality and their associated factors among women delivering at Harare Maternity Hospital, Zimbabwe: a cross-sectional retrospective analysis. BMC Pregnancy and Childbirth 2005, 5(1):9.

54. Fretts RC, Schmittdiel J, McLean FH, Usher RH, Goldman MB: Increased maternal age and the risk of fetal death. The New England journal of medicine 1995, 333(15):953-957.

55. Fretts RC, Usher RH: Causes of fetal death in women of advanced maternal age. Obstetrics \& Gynecology 1997, 89(1):40-45.

56. Gadow EC, Castilla EE, Lopez Camelo J, Queenan JT: Stillbirth rate and associated risk factors among 869750 Latin American hospital births 1982-1986. International Journal of Gynecology \& Obstetrics 1991, 35(3):209-214

57. Glinianaia SV, Rankin J, Bell R, Pearce MS, Parker L: Temporal changes in the distribution of population risk factors attenuate the reduction in perinatal mortality. Journal of clinical epidemiology 2005, 58(12):1299-1307.

58. Haglund B, Cnattingius S, Nordström ML: Social differences in late fetal death and infant mortality in Sweden 1985-86. Paediatric and perinatal epidemiology 1993, 7(1):33-44

59. Heimann F, Messerer D, Baltzer J: Pregnancy, labor and fetal outcome in females over 40 years of age]. Geburtshilfe und Frauenheilkunde 1993, 53(6):411.

60. Jacobsson B, Ladfors $L$, Milsom I: Advanced maternal age and adverse perinatal outcome. Obstetrics \& Gynecology 2004, 104(4):727.

61. Jolly M, Sebire N, Harris J, Robinson S, Regan L: The risks associated with pregnancy in women aged 35 years or older. Human Reproduction 2000, 15(11):2433.

62. Khandait DW, Ambadekar NN, Zodpey SP, Vasudeo ND: Maternal age as a risk factor for stillbirth. Indian J Public Health 2000, 44(1):28-30
63. Kristensen J, Vestergaard M, Wisborg K, Kesmodel U, Secher NJ: Pre pregnancy weight and the risk of stillbirth and neonatal death. BJOG: An International Journal of Obstetrics \& Gynaecology 2005, 112(4):403-408.

64. Lammer EJ, Brown LE, Anderka MT, Guyer B: Classification and analysis of fetal deaths in Massachusetts. JAMA: The Journal of the American Medical Association 1989, 261(12):1757.

65. Miller DA: Is advanced maternal age an independent risk factor for uteroplacental insufficiency? American journal of obstetrics and gynecology 2005, 192(6):1974-1980.

66. Naeye RL: Maternal age, obstetric complications, and the outcome of pregnancy. Obstetrics and gynecology 1983, 61(2):210.

67. Nybo Andersen AMN, Wohlfahrt J, Christens P, Olsen J, Melbye M: Maternal age and fetal loss: population based register linkage study. BMJ 2000, 320(7251):1708.

68. Pugliese A, Vicedomini D, Arsieri R: Perinatal outcomes of newborn infants of mothers over 40 years old. A case-control study. Minerva ginecologica 1997, 49(3):81.

69. Rasmussen S, Albrechtsen S, Irgens LM, Dalaker K, Maartmann-Moe H, Vlatkovic L, Markestad T: Risk factors for unexplained antepartum fetal death in Norway 1967-1998. Early human development 2003, 71(1):39-52.

70. Raymond EG, Cnattingius S, Kiely JL: Effects of maternal age, parity, and smoking on the risk of stillbirth. BJOG: An International Journal of Obstetrics \& Gynaecology 1994, 101(4):301-306.

71. Reddy UM, Ko CW, Willinger M: Maternal age and the risk of stillbirth throughout pregnancy in the United States. American journal of obstetrics and gynecology 2006, 195(3):764-770.

72. Roman H, Robillard PY, Julien C, Kauffmann E, Laffitte A, Gabriele M Marpeau L, Barau G: Pregnancy beyond age 40 in 382 women: a retrospective study in Reunion Island. Journal de gynécologie, obstétrique et biologie de la reproduction 2004, 33(7):615

73. Seoud MA, Nassar AH, Usta IM, Melhem Z, Kazma A, Khalil AM: Impact of advanced maternal age on pregnancy outcome. American journal of perinatology 2002, 19(1):1

74. Sheiner E, Hallak M, Shoham-Vardi I, Goldstein D, Mazor M, Katz M: Determining risk factors for intrapartum fetal death. The Journal of reproductive medicine 2000, 45(5):419.

75. Tough SC, Newburn-Cook C, Johnston DW, Svenson LW, Rose S, Belik J: Delayed childbearing and its impact on population rate changes in lower birth weight, multiple birth, and preterm delivery. Pediatrics 2002, 109(3):399.

76. Viegas OAC, Leong WP, Ahmed S, Ratnam SS: Obstetrical outcome with increasing maternal age. Journal of biosocial science 1994, 26(02):261-267.

77. Ziadeh SM: Maternal and perinatal outcome in nulliparous women aged 35 and older. Gynecologic and obstetric investigation 2002, 54(1):6-10.

78. Ferraz EM, Gray RH: A case-control study of stillbirths in northeast Brazil. International Journal of Gynecology \& Obstetrics 1991, 34(1):13-19.

79. Little RE, Weinberg CA: Risk factors for antepartum and intrapartum stillbirth. American journal of epidemiology 1993, 137(11):1177.

80. Meda N, Traore GS, Meda HA, Curtis V: La mortinatalité au Burkina Faso: facteurs de risque en milieu urbain de Bobo-Dioulasso. Ann Soc belge Mod trop 1991, 71:307-316

81. Petridou E, Kotsifakis G, Revinthi K, Polychronopoulou A, Trichopoulos D: Determinants of stillbirth mortality in Greece. Sozial-und Präventivmedizin/ Social and Preventive Medicine 1996, 41(2):70-78.

82. Smeeton NC, Rona RJ, Dobson P, Cochrane R, Wolfe C: Assessing the determinants of stillbirths and early neonatal deaths using routinely collected data in an inner city area. BMC medicine 2004, 2(1):27.

83. Stephansson O, Dickman PW, Johansson A, Cnattingius S: Maternal weight, pregnancy weight gain, and the risk of antepartum stillbirth* 1 . American journal of obstetrics and gynecology 2001, 184(3):463-469.

84. Metcalfe S, Jacques A, Archibald A, Burgess T, Collins V, Henry A, McNamee $K$, Sheffield $L$, Slater $H$, Wake $S$ : A model for offering carrier screening for fragile $X$ syndrome to nonpregnant women: results from a pilot study. Genetics in Medicine 2008, 10(7):525.

85. Almutawa FJ, Cabfm JRA: Outcome of premarital counseling of hemoglobinopathy carrier couples attending premarital services in Bahrain. old and still counting our success 2009, 217.

86. AlHamdan NAR, AlMazrou YY, AISwaidi FM, Choudhry AJ: Premarital screening for thalassemia and sickle cell disease in Saudi Arabia. Genetics in Medicine 2007, 9(6):372. 
87. Al Sulaiman A, Saeedi M, Al Suliman A, Owaidah T: Postmarital follow up survey on high risk patients subjected to premarital screening program in Saudi Arabia. Prenatal diagnosis 2010, 30(5):478-481.

88. Tamhankar PM, Agarwal S, Arya V, Kumar R, Gupta UR, Agarwal SS: Prevention of homozygous beta thalassemia by premarital screening and prenatal diagnosis in India. Prenatal diagnosis 2009, 29(1):83-88.

89. Kirke PN, Daly LE, Elwood JH: A randomised trial of low dose folic acid to prevent neural tube defects. The Irish Vitamin Study Group. British Medical Journal 1992, 67(12):1442.

90. Laurence KM, James N, Miller MH, Tennant GB, Campbell H: Double-blind randomised controlled trial of folate treatment before conception to prevent recurrence of neural-tube defects. British medical journal (Clinical research ed) 1981, 282(6275):1509.

91. Prevention of neural tube defects: results of the Medical Research Council Vitamin Study. MRC Vitamin Study Research Group. Lancet 1991, 338(760):131-137.

92. Suarez L, Hendricks KA, Cooper SP, Sweeney AM, Hardy RJ, Larsen RD: Neural tube defects among Mexican Americans living on the US-Mexico border: effects of folic acid and dietary folate. American journal of epidemiology 2000, 152(11):1017-1023.

93. Vergel RG, Sanchez LR, Heredero BL, Rodriguez PL, Martinez AJ: Primary prevention of neural tube defects with folic acid supplementation: Cuban experience. Prenatal diagnosis 1990, 10(3):149-152.

94. World Health Organization: Prevention of Neural Tube Defects.Standards for Maternal and Neonatal Care. Geneva, Switzerland: World Health Organization; 2009.

95. Berger J, T H, Cavalli-Sforza T, Smitasiri S, Khan NC, Milani S: Community mobilization and social marketing to promote weekly iron-folic acid supplementation in women of reproductive age in Vietnam: impact on anemia and iron status. 2005

96. Angeles-Agdeppa I, P L, Ramos AC, Etorma UM, Cavalli-Sforza T, Milani S: Government-Industry Partnership in Weekly Iron-Folic Acid Supplementation for Women of Reproductive Age in the Philippines. 2005.

97. Khambalia AZ, O'Connor DL, Macarthur C, Dupuis A, Zlotkin SH: Periconceptional iron supplementation does not reduce anemia or improve iron status among pregnant women in rural Bangladesh. The American journal of clinical nutrition 2009, 90(5):1295-1302.

98. Casey GJ, J D, Phuc TQ, Tinh $\Pi$, Tho DH: Long-term weekly iron-folic acid and de-worming is associated with stabilised haemoglobin and increasing iron stores in non-pregnant women in Vietnam. 2010.

99. Passerini L, C G, Biggs BA, Cong DT, Phu LB, Phuc TQ, Carone M, Montresor $A$ : Increased birth weight associated with regular prepregnancy deworming and weekly iron-folic acid supplementation for Vietnamese women. 2012

100. Vir SC, S N, Nigam AK, Jain R: Weekly iron and folic acid supplementation with counseling reduces anemia in adolescent girls. 2008.

101. Bhutta ZA, Chopra M, Axelson H, Berman P, Boerma T, Bryce J, Bustreo F, Cavagnero E, Cometto G, Daelmans B: Countdown to 2015 decade report (2000-10): taking stock of maternal, newborn, and child survival. Lancet 2010, 375(9730):2032-2044.

102. Klerman LV, Cliver SP, Goldenberg RL: The impact of short interpregnancy intervals on pregnancy outcomes in a low-income population. American Journal of Public Health 1998, 88(8):1182.

103. Shults RA, Arndt V, Olshan AF, Martin CF, Royce RA: Effects of short interpregnancy intervals on small-for-gestational age and preterm births. Epidemiology 1999, 10(3):250.

104. Cecatti JG, Correa-Silva EPB, Milanez H, Morais SS, Souza JP: The associations between inter-pregnancy interval and maternal and neonatal outcomes in Brazil. Maternal and Child Health Journal 2008, 12(2):275-281.

105. Conde-Agudelo A, Belizán JM, Norton MH, Rosas-Bermúdez A: Effect of the interpregnancy interval on perinatal outcomes in Latin America. Obstetrics \& Gynecology 2005, 106(2):359.

106. Conde-Agudelo A, Belizan JM, Breman R, Brockman SC, Rosas-Bermudez A: Effect of the interpregnancy interval after an abortion on maternal and perinatal health in Latin America. International Journal of Gynecology \& Obstetrics 2005, 89:S34-S40.

107. Conde-Agudelo A, Rosas-Bermúdez A, Kafury-Goeta AC: Birth spacing and risk of adverse perinatal outcomes: a meta-analysis. JAMA 2006, 295(15):1809.

108. DeFranco EA, Stamilio DM, Boslaugh SE, Gross GA, Muglia LJ: A short interpregnancy interval is a risk factor for preterm birth and its recurrence. American Journal of Obstetrics and Gynecology 2007, 197(3):264.
109. Ekwo EE, Moawad A: The relationship of interpregnancy interval to the risk of preterm births to black and white women. International journal of epidemiology 1998, 27(1):68.

110. Ferraz EM, Gray RH, Fleming PL, Maia TM: Interpregnancy interval and low birth weight: findings from a case-control study. American journal of epidemiology 1988, 128(5):1111

111. Fuentes-Afflick E, Hessol NA: Interpregnancy interval and the risk of premature infants. Obstetrics \& Gynecology 2000, 95(3):383.

112. Grisaru-Granovsky S, Gordon ES, Haklai Z, Samueloff A, Schimmel MM: Effect of interpregnancy interval on adverse perinatal outcomes-a national study. Contraception 2009, 80(6):512-518.

113. Nabukera SK, Wingate MS, Kirby RS, Owen J, Swaminathan S, Alexander GR, Salihu HM: Interpregnancy interval and subsequent perinatal outcomes among women delaying initiation of childbearing. Journal of Obstetrics and Gynaecology Research 2008, 34(6):941-947.

114. Rodrigues $\mathrm{T}$, Barros $\mathrm{H}$ : Short interpregnancy interval and risk of spontaneous preterm delivery. European Journal of Obstetrics \& Gynecology and Reproductive Biology 2008, 136(2):184-188.

115. Smith G, Pell JP, Dobbie R: Interpregnancy interval and risk of preterm birth and neonatal death: retrospective cohort study. BMJ 2003, 327(7410):313.

116. Zhu BP, Rolfs RT, Nangle BE, Horan JM: Effect of the interval between pregnancies on perinatal outcomes. New England Journal of Medicine 1999, 340(8):589.

117. Arafa MA, Alkhouly A, Youssef ME: Influence of inter pregnancy interval on preterm delivery. Paediatric and Perinatal Epidemiology 2004, 18(4):248-252.

118. Lieberman E, Lang JM, Ryan KJ, Monson RR, Schoenbaum SC: The association of inter-pregnancy interval with small for gestational age births. Obstetrics \& Gynecology 1989, 74(1):1.

119. van Eijsden M, Smits LJM, van der Wal MF, Bonsel GJ: Association between short interpregnancy intervals and term birth weight: the role of folate depletion. American Journal of Clinical Nutrition 2008, 88(1):147.

120. DaVanzo J, Hale L, Razzaque A, Rahman M: Effects of interpregnancy interval and outcome of the preceding pregnancy on pregnancy outcomes in Matlab, Bangladesh. BJOG: An International Journal of Obstetrics \& Gynaecology 2007, 114(9):1079-1087.

121. Love ER, Bhattacharya S, Smith NC: Effect of interpregnancy interval on outcomes of pregnancy after miscarriage: retrospective analysis of hospital episode statistics in Scotland. British Medical Journal 2010 341(aug05 2):c3967.

122. Stephansson O, Dickman PW, Cnattingius S: The influence of interpregnancy interval on the subsequent risk of stillbirth and early neonatal death. Obstetrics \& Gynecology 2003, 102(1):101.

123. Solo J, Billings DL, Aloo-Obunga C, Ominde A, Makumi M: Creating linkages between incomplete abortion treatment and family planning services in Kenya. 1999.

124. Ota E, Haruna M, Suzuki M, Anh DD, Tho LH, Tam NTT, Thiem VD, Anh NTH, Isozaki M, Shibuya K: Maternal body mass index and gestational weight gain and their association with perinatal outcomes in Viet Nam. Bulletin of the World Health Organization 2011, 89(2):127-136.

125. Doherty DA, Magann EF, Francis J, Morrison JC, Newnham JP: Prepregnancy body mass index and pregnancy outcomes. International Journal of Gynecology \& Obstetrics 2006, 95(3):242-247.

126. Abenhaim HA, Kinch RA, Morin L, Benjamin A, Usher R: Effect of prepregnancy body mass index categories on obstetrical and neonatal outcomes. Archives of Gynecology and Obstetrics 2007, 275(1):39-43.

127. Chen A, Klebanoff MA, Basso O: Pre-pregnancy body mass index change between pregnancies and preterm birth in the following pregnancy. Paediatric and Perinatal Epidemiology 2009, 23(3):207-215.

128. Driul L, Cacciaguerra G, Citossi A, Martina MD, Peressini L, Marchesoni D: Prepregnancy body mass index and adverse pregnancy outcomes. Archives of Gynecology and Obstetrics 2008, 278(1):23-26.

129. Johnson TS, Rottier KJ, Luellwitz A, Kirby RS: Maternal prepregnancy body mass index and delivery of a preterm infant in Missouri 1998-2000. Public Health Nursing 2009, 26(1):3-13.

130. Kosa JL, Guendelman S, Pearl M, Graham S, Abrams B, Kharrazi M: The Association Between Pre-pregnancy BMI and Preterm Delivery in a Diverse Southern California Population of Working Women. Maternal and Child Health Journal 2010, 1-10.

131. Murakami M, Ohmichi M, Takahashi T, Shibata A, Fukao A, Morisaki N, Kurachi $\mathrm{H}$ : Prepregnancy body mass index as an important predictor of 
perinatal outcomes in Japanese. Archives of Gynecology and Obstetrics 2005, 271(4):311-315.

132. Ronnenberg AG, Wang X, Xing H, Chen C, Chen D, Guang W, Guang A, Wang $L$, Ryan $L, X u X$ : Low preconception body mass index is associated with birth outcome in a prospective cohort of Chinese women. Journal of Nutrition 2003, 133(11):3449.

133. Salihu HM, Mbah AK, Alio AP, Clayton HB, Lynch O: Low pre-pregnancy body mass index and risk of medically indicated versus spontaneous preterm singleton birth. European Journal of Obstetrics \& Gynecology and Reproductive Biology 2009, 144(2):119-123.

134. Wise LA, Palmer JR, Heffner LJ, Rosenberg L: Prepregnancy body size, gestational weight gain, and risk of preterm birth in African-American women. Epidemiology 2010, 21(2):243.

135. Chen CW, Tsai CY, Sung FC, Lee YY, Lu TH, Li CY, Ko MC: Adverse birth outcomes among pregnancies of teen mothers: age specific analysis of national data in Taiwan. Child: Care, Health and Development 2010, 36(2):232-240.

136. Gilboa SM, Correa A, Alverson CJ: Use of spline regression in an analysis of maternal prepregnancy body mass index and adverse birth outcomes: does it tell us more than we already know? Annals of epidemiology 2008, 18(3):196-205.

137. Han YS, Ha EH, Park HS, Kim YJ, Lee SS: Relationships between pregnancy outcomes, biochemical markers and pre-pregnancy body mass index. International Journal of Obesity 2010.

138. Nohr EA, Vaeth M, Baker JL, Sorensen TIA, Olsen J, Rasmussen KM: Combined associations of prepregnancy body mass index and gestational weight gain with the outcome of pregnancy. American Journal of Clinical Nutrition 2008, 87(6):1750.

139. Watanabe H, Inoue K, Doi M, Matsumoto M, Ogasawara K, Fukuoka H, Nagai $Y$ : Risk factors for term small for gestational age infants in women with low prepregnancy body mass index. Journal of Obstetrics and Gynaecology Research 2010, 36(3):506-512.

140. Frederick IO, Williams MA, Sales AE, Martin DP, Killien M: Pre-pregnancy body mass index, gestational weight gain, and other maternal characteristics in relation to infant birth weight. Maternal and Child Health Journal 2008, 12(5):557-567.

141. Yekta Z, Ayatollahi H, Porali R, Farzin A: The effect of pre-pregnancy body mass index and gestational weight gain on pregnancy outcomes in urban care settings in Urmia-Iran. BMC Pregnancy and Childbirth 2006, 6(1):15.

142. Chu SY, Bachman DJ, Callaghan WM, Whitlock EP, Dietz PM, Berg CJ, O'Keeffe-Rosetti M, Bruce FC, Hornbrook MC: Association between obesity during pregnancy and increased use of health care. New England Journal of Medicine 2008, 358(14):1444.

143. Nohr EA, Bech BH, Davies MJ, Frydenberg M, Henriksen TB, Olsen J: Prepregnancy obesity and fetal death: a study within the Danish National Birth Cohort. Obstetrical \& gynecological survey 2005, 61(1):7.

144. Dietz PM, Callaghan WM, Morrow B, Cogswell ME: Population-based assessment of the risk of primary cesarean delivery due to excess prepregnancy weight among nulliparous women delivering term infants. Maternal and Child Health Journal 2005, 9(3):237-244.

145. Getahun D, Ananth CV, Peltier MR, Salihu HM, Scorza WE: Changes in prepregnancy body mass index between the first and second pregnancies and risk of large-for-gestational-age birth. American Journal of Obstetrics and Gynecology 2007, 196(6):530.

146. LaCoursiere D, Bloebaum L, Duncan JD, Varner MW: Population-based trends and correlates of maternal overweight and obesity, Utah 19912001. American journal of obstetrics and gynecology 2005, 192(3):832-839.

147. Fortner RT, Pekow P, Solomon CG, Markenson G, Chasan-Taber L: Prepregnancy body mass index, gestational weight gain, and risk of hypertensive pregnancy among Latina women. American Journal of Obstetrics and Gynecology 2009, 200(2):167-167.

148. Samuels-Kalow ME, Funai EF, Buhimschi C, Norwitz E, Perrin M, CalderonMargalit R, Deutsch L, Paltiel O, Friedlander Y, Manor O: Prepregnancy body mass index, hypertensive disorders of pregnancy, and long-term maternal mortality. American Journal of Obstetrics and Gynecology 2007, 197(5):490.

149. Leeners B, Rath W, Kuse S, Irawan C, Imthurn B, Neumaier-Wagner P: BMI: new aspects of a classical risk factor for hypertensive disorders in pregnancy. Clinical Science 2006, 111:81-86.

150. Saftlas AF, Wang W, Risch H, Woolson R, Hsu CD, Bracken MB: Prepregnancy body mass index and gestational weight gain as risk factors for preeclampsia and transient hypertension. Annals of epidemiology 2000, 10(7):475-475.

151. Gilboa SM, Correa A, Botto LD, Rasmussen SA, Waller DK, Hobbs CA, Cleves MA, Riehle-Colarusso TJ: Association between prepregnancy body mass index and congenital heart defects. American Journal of Obstetrics and Gynecology 2010, 202(1):51

152. Oddy WH, De Klerk NH, Miller M, Payne J, Bower C: Association of maternal pre pregnancy weight with birth defects: Evidence from a case-control study in Western Australia. Australian and New Zealand Journal of Obstetrics and Gynaecology 2009, 49(1):11-15.

153. Waller DK, Shaw GM, Rasmussen SA, Hobbs CA, Canfield MA, Siega-Riz AM, Gallaway MS, Correa A: Prepregnancy obesity as a risk factor for structural birth defects. Archives of Pediatrics and Adolescent Medicine 2007, 161(8):745.

154. Li Z, Liu J, Ye R, Zhang L, Pei L, Zheng X, Ren A: Maternal prepregnancy body mass index and risk of neural tube defects: A population-based case-control study in Shanxi province, China. Birth Defects Research Part A: Clinical and Molecular Teratology 2010

155. Waller DK, Tita ATN, Werler MM, Mitchell AA: Association between prepregnancy maternal body mass index and the risk of having an infant with a congenital diaphragmatic hernia. Birth Defects Research Part A: Clinical and Molecular Teratology 2003, 67(1):73-76.

156. Amorim Adegboye AR, Linne YM, Lourenco PMC: Diet or exercise, or both, for weight reduction in women after childbirth. status and date: Edited (no change to conclusions), published in 2007, 4.

157. Kinnunen TI, Pasanen M, Aittasalo M, Fogelholm M, Weiderpass E, Luoto R: Reducing postpartum weight retention - a pilot trial in primary health care. Nutrition Journal 2007, 6(1):21.

158. Black MM, Hager ER, Le K, Anliker J, Arteaga SS, DiClemente C, Gittelsohn J, Magder L, Papas M, Snitker S: Challenge! Health Promotion/Obesity Prevention Mentorship Model Among Urban, Black Adolescents. Pediatrics 2010, 126(2):280

159. Eiben G, Lissner L: Health Hunters-an intervention to prevent overweight and obesity in young high-risk women. International journal of obesity 2005, 30(4):691-696.

160. Faucher MA, Mobley J: A Community Intervention on Portion Control Aimed at Weight Loss in Low-Income Mexican American Women. Journal of Midwifery \& Women's Health 2010, 55(1):60-64.

161. Gokee LaRose J, Tate DF, Gorin AA, Wing RR: Preventing Weight Gain in Young Adults:: A Randomized Controlled Pilot Study. American journal of preventive medicine 2010.

162. Ostbye T, Krause KM, Lovelady CA, Morey MC, Bastian LA, Peterson BL, Swamy GK, Brouwer RJN, McBride CM: Active Mothers Postpartum:: A Randomized Controlled Weight-Loss Intervention Trial. American journal of preventive medicine 2009, 37(3):173-180.

163. Chang MW, Nitzke S, Brown R: Design and Outcomes of a Mothers In Motion Behavioral Intervention Pilot Study. Journal of Nutrition Education and Behavior 2010, 42(3S):11-21.

164. Harvey-Berino J, West D, Krukowski R, Prewitt E, VanBiervliet A, Ashikaga T, Skelly J: Internet delivered behavioral obesity treatment. Preventive medicine 2010.

165. Mediano MFF, Barbosa JSO, Moura AS, Willett WC, Sichieri R: A randomized clinical trial of home-based exercise combined with a slight caloric restriction on obesity prevention among women. Preventive medicine 2010.

166. Rock CL, Flatt SW, Sherwood NE, Karanja N, Pakiz B, Thomson CA: Effect of a Free Prepared Meal and Incentivized Weight Loss Program on Weight Loss and Weight Loss Maintenance in Obese and Overweight Women. JAMA: The Journal of the American Medical Association 2010, 304(16):1803.

167. Philliber S, Kaye J, Herrling S: The national evaluation of the Children's Aid Society Carrera-Model Program to prevent teen pregnancy. Accord, NY: Philliber Research Associates 2001.

168. Solomon R, Liefeld CP: Effectiveness of a family support center approach to adolescent mothers: Repeat pregnancy and school drop-out rates. Family Relations 1998, 47(2):139-144.

169. Allen JP, Philliber S, Herrling S, Kuperminc GP: Preventing teen pregnancy and academic failure: Experimental evaluation of a developmentally based approach. Child Development 1997, 68(4):729-742.

170. Schillinger J, Kissinger $P$, Calvet $H$, et al: Patient-delivered partner treatment with azithromycin to prevent repeated Chlamydia trachomatis infection among women: a randomized, controlled trial. Sexually Transmitted Diseases 2003, 30(1):49. 
171. Branson BM, Peterman TA, Cannon RO, Ransom R, Zaidi AA: Group counseling to prevent sexually transmitted disease and HIV: a randomized controlled trial. Sexually Transmitted Diseases 1998, 25(10):553-560

172. Boyer CB, Barrett DC, Peterman TA, Bolan G: Sexually transmitted disease (STD) and HIV risk in heterosexual adults attending a public STD clinic: evaluation of a randomized controlled behavioral risk-reduction intervention trial. Aids 1997, 11(3):359-367.

173. Kamb ML, Fishbein M, Douglas JM Jr, Rhodes F, Rogers J, Bolan G, Zenilman J, Hoxworth T, Malotte CK, latesta M: Efficacy of risk-reduction counseling to prevent human immunodeficiency virus and sexually transmitted diseases: a randomized controlled trial. Jama 1998, 280(13):1161.

174. Shain RN, Piper JM, Holden AEC, Champion JD, Perdue ST, Korte JE, Guerra FA: Prevention of gonorrhea and chlamydia through behavioral intervention: results of a two-year controlled randomized trial in minority women. Sexually transmitted diseases 2004, 31(7):401.

175. Shain RN, Piper JM, Newton ER, Perdue ST, Ramos R, Champion JD, Guerra FA: A randomized, controlled trial of a behavioral intervention to prevent sexually transmitted disease among minority women. New England Journal of Medicine 1999, 340(2):93.

176. Bunnell R, Ekwaru JP, Solberg P, Wamai N, Bikaako-Kajura W, Were W, Coutinho A, Liechty C, Madraa E, Rutherford G: Changes in sexual behavior and risk of HIV transmission after antiretroviral therapy and prevention interventions in rural Uganda. Aids 2006, 20(1):85.

177. Matthews LT, Baeten JM, Celum C, Bangsberg DR: Periconception preexposure prophylaxis to prevent HIV transmission: benefits, risks, and challenges to implementation. AIDS 2010, 24(13):1975.

178. Peterson L, Taylor D, Roddy R, Belai G, Phillips P, Nanda K, Grant R, Clarke EEK Doh AS, Ridzon R: Tenofovir disoproxil fumarate for prevention of HIV infection in women: a phase 2, double-blind, randomized, placebocontrolled trial. PLoS Hub for Clinical Trials 2007, 2(5):e27.

179. Auvert B, Taljaard D, Lagarde E, Sobngwi-Tambekou J, Sitta R, Puren A Randomized, controlled intervention trial of male circumcision for reduction of HIV infection risk: the ANRS 1265 Trial. PLoS Medicine 2005, 2(11):1112.

180. Bailey RC, Moses S, Parker CB, Agot K, Maclean I, Krieger JN, Williams CFM, Campbell RT, Ndinya-Achola JO: Male circumcision for HIV prevention in young men in Kisumu, Kenya: a randomised controlled trial. The Lancet 2007, 369(9562):643-656.

181. Gray RH, Kigozi G, Serwadda D, Makumbi F, Watya S, Nalugoda F, Kiwanuka N, Moulton LH, Chaudhary MA, Chen MZ: Male circumcision for HIV prevention in men in Rakai, Uganda: a randomised trial. The Lancet 2007, 369(9562):657-666.

182. Wawer MJ, Makumbi F, Kigozi G, Serwadda D, Watya S, Nalugoda F, Buwembo D, Ssempijja V, Kiwanuka N, Moulton LH: Circumcision in HIVinfected men and its effect on HIV transmission to female partners in Rakai, Uganda: a randomised controlled trial. The Lancet 2009, 374(9685):229-237.

183. Weiss HA, Quigley MA, Hayes RJ: Male circumcision and risk of HIV infection in sub-Saharan Africa: a systematic review and meta-analysis. Aids 2000, 14(15):2361.

184. Karim SA, Coletti A, Richardson B, Ramjee G, Hoffman I, Chirenje M, Taha T, Kapina M, Maslankowski L, Soto-Torres L: Safety and effectiveness of vaginal microbicides BufferGel and 0.5\% PRO 2000/5 gel for the prevention of HIV infection in women: results of the HPTN 035 trial. : 2009 2009, 8-11.

185. Abdool Karim Q, Abdool Karim SS, Frohlich JA, Grobler AC, Baxter C, Mansoor LE, Kharsany A, Sibeko S, Mlisana KP, Omar Z: Effectiveness and safety of tenofovir gel, an antiretroviral microbicide, for the prevention of HIV infection in women. Science 2010, 329(5996):1168.

186. McCormack S, Ramjee G, Kamali A, Rees H, Crook AM, Gafos M, Jentsch U, Pool R, Chisembele M, Kapiga S: PRO2000 vaginal gel for prevention of HIV-1 infection (Microbicides Development Programme 301): a phase 3, randomised, double-blind, parallel-group trial. The Lancet 2010, 376(9749):1329-1337.

187. Skoler-Karpoff S, Ramjee G, Ahmed K, Altini L, Plagianos MG, Friedland B, Govender S, De Kock A, Cassim N, Palanee T: Efficacy of Carraguard for prevention of HIV infection in women in South Africa: a randomised, double-blind, placebo-controlled trial. The Lancet 2008, 372(9654):1977-1987.

188. Ahmed S, Lutalo T, Wawer M, Serwadda D, Sewankambo NK, Nalugoda F, Makumbi F, Wabwire-Mangen F, Kiwanuka N, Kigozi G: HIV incidence and sexually transmitted disease prevalence associated with condom use: a population study in Rakai, Uganda. Aids 2001, 15(16):2171.
189. Davis KR, Weller SC: The effectiveness of condoms in reducing heterosexual transmission of HIV. Family Planning Perspectives 1999, 31(6):272-279.

190. Pinkerton SD, Abramson PR: Effectiveness of condoms in preventing HIV transmission. Social Science \& Medicine 1997, 44(9):1303-1312.

191. Weller S, Davis K: Condom effectiveness in reducing heterosexual HIV transmission. Cochrane Database Syst Rev 2002, 1:1-22.

192. Padian NS, van der Straten A, Ramjee G, Chipato T, de Bruyn G, Blanchard K, Shiboski S, Montgomery ET, Fancher H, Cheng H: Diaphragm and lubricant gel for prevention of HIV acquisition in southern African women: a randomised controlled trial. The Lancet 2007, 370(9583):251-261.

193. Coates TJ: Efficacy of voluntary HIV-1 counselling and testing in individuals and couples in Kenya, Tanzania, and Trinidad: a randomised trial. Lancet 2000, 356(9224):103-112.

194. Denison JA, O'Reilly KR, Schmid GP, Kennedy CE, Sweat MD: HIV voluntary counseling and testing and behavioral risk reduction in developing countries: a meta-analysis, 1990-2005. AIDS and Behavior 2008, 12(3):363-373.

195. Vidanapathirana J, Abramson MJ, Forbes A, Fairley C: Mass media interventions for promoting HIV testing. Cochrane database of systematic reviews (Online) 2005, , 3: CD004775.

196. Celum C, Wald A, Lingappa JR, Magaret AS, Wang RS, Mugo N, Mujugira A, Baeten JM, Mullins JI, Hughes JP: Acyclovir and transmission of HIV-1 from persons infected with HIV-1 and HSV-2. New England journal of medicine 2010, 362(5):427-439.

197. Grosskurth H, Todd J, Mwijarubi E, Mayaud P, Nicoll A: Impact of improved treatment of sexually transmitted diseases on HIV infection in rural Tanzania: randomised controlled trial. The Lancet 1995, 346(8974):530-536.

198. Kamali A, Quigley M, Nakiyingi J, Kinsman J, Kengeya-Kayondo J, Gopal R, Ojwiya A, Hughes P, Carpenter LM, Whitworth J: Syndromic management of sexually-transmitted infections and behaviour change interventions on transmission of HIV-1 in rural Uganda: a community randomised trial. The Lancet 2003, 361(9358):645-652.

199. Wawer MJ, Sewankambo NK, Serwadda D, Quinn TC, Paxton LA, Kiwanuka N, Wabwire-Mangen F, Li C, Lutalo T, Nalugoda F: Control of sexually transmitted diseases for AIDS prevention in Uganda: a randomised community trial. The Lancet 1999, 353(9152):525-535.

200. Goldfarb E, Donnelly J, Duncan DF, Young M, Eadie C, Castiglia D: Evaluation of an abstinence-based curriculum for early adolescents: First year changes in sex attitudes, knowledge, and behavior. North American Journal of Psychology 1999, 1:243-254.

201. Jemmott JB, Sweet Jemmott L, Fong GT: Abstinence and safer sex HIV risk-reduction interventions for African American adolescents. JAMA: The Journal of the American Medical Association 1998, 279(19):1529.

202. Trenholm C, Devaney B, Fortson K, Quay L, Wheeler J, Clark M: Impacts of four Title V, Section 510 abstinence education programs. Princeton, $\mathrm{NJ}$ : Mathematica Policy Research, Inc 2007.

203. Boekeloo BO, Schamus LA, Simmens SJ, Cheng TL, O'Connor K, D'Angelo LJ: A STD/HIV prevention trial among adolescents in managed care. Pediatrics 1999, 103(1):107.

204. Dilorio C, Resnicow K, McCarty F, De AK, Dudley WN, Wang DT, Denzmore P: Keepin'it REAL!: Results of a mother-adolescent HIV prevention program. Nursing research 2006, 55(1):43.

205. Kirby D, Korpi M, Barth RP, Cagampang HH: The impact of the Postponing Sexual Involvement curriculum among youths in California. Family Planning Perspectives 1997, 29(3):100-108.

206. Sikkema KJ, Anderson ES, Kelly JA, Winett RA, Gore-Felton C, Roffman RA, Heckman TG, Graves K, Hoffmann RG, Brondino MJ: Outcomes of a randomized, controlled community-level HIV prevention intervention for adolescents in low-income housing developments. Aids 2005, 19(14):1509.

207. Stanton BF, Xiaoming LI, Ricardo I, Galbraith J, Feigelman S, Kaljee L: A randomized, controlled effectiveness trial of an AIDS prevention program for low-income African-American youths. Archives of pediatrics \& adolescent medicine 1996, 150(4):363-372.

208. Stanton B, Harris C, Cottrell L, Li X, Gibson C, Guo J, Pack R, Galbraith J, Pendleton S, Wu Y: Trial of an urban adolescent sexual risk-reduction intervention for rural youth: a promising but imperfect fit. Journal of Adolescent Health 2006, 38(1):55, e25-55. e36.

209. Weeks K, Levy SR, Gordon AK, Handler A, Perhats C, Flay BR: Does parental involvement make a difference? The impact of parent interactive activities on students in a school-based AIDS prevention program. AIDS education and prevention 1997, 9(1):90-106. 
210. Wu Y, Stanton BF, Galbraith J, Kaljee L, Cottrell L, Li X, Harris CV, D'Alessandri D, Burns JM: Sustaining and broadening intervention impact: a longitudinal randomized trial of 3 adolescent risk reduction approaches. Pediatrics 2003, 111(1):e32.

211. Crepaz N, Horn AK, Rama SM, Griffin T, Deluca JB, Mullins MM, Aral SO: The efficacy of behavioral interventions in reducing HIV risk sex behaviors and incident sexually transmitted disease in black and Hispanic sexually transmitted disease clinic patients in the United States: A meta-analytic review. Sexually Transmitted Diseases 2007, 34(6):319.

212. Crepaz N, Marks G, Liau A, Mullins MM, Aupont LW, Marshall K, Jacobs ED, Wolitski RJ: Prevalence of unprotected anal intercourse among HIVdiagnosed MSM in the United States: a meta-analysis. Aids 2009, 23(13):1617.

213. Darbes L, Crepaz N, Lyles C, Kennedy G, Rutherford G: The efficacy of behavioral interventions in reducing HIV risk behaviors and incident sexually transmitted diseases in heterosexual African Americans. Aids 2008, 22(10):1177.

214. Gowing L, Farrell M, Bornemann R, Sullivan LE, Ali R: Substitution treatment of injecting opioid users for prevention of HIV infection (Review). 2008.

215. Huedo-Medina TB, Boynton MH, Warren MR, LaCroix JM, Carey MP, Johnson BT: Efficacy of HIV prevention interventions in Latin American and Caribbean Nations, 1995-2008: a meta-analysis. AIDS and Behavior 2010, 1-15.

216. Johnson BT, Scott-Sheldon LAJ, Smoak ND, LaCroix JM, Anderson JR, Carey MP: Behavioral Interventions for African-Americans to Reduce Sexual Risk of HIV: A Meta-Analysis of Randomized Controlled Trials. Journal of acquired immune deficiency syndromes (1999) 2009, 51(4):492.

217. Kennedy CE, Medley AM, Sweat MD, O'Reilly KR: Behavioural interventions for HIV positive prevention in developing countries: a systematic review and meta-analysis. Bulletin of the World Health Organization 2010, 88(8):615-623.

218. MacNeil JM, Mberesero F, Kilonzo G: Is care and support associated with preventive behaviour among people with HIV? AIDS care 1999, 11(5):537-546

219. Marks G, Crepaz N, Janssen RS: Estimating sexual transmission of HIV from persons aware and unaware that they are infected with the virus in the USA. Aids 2006, 20(10):1447.

220. Neumann MS, Johnson WD, Semaan S, Flores SA, Peersman G, Hedges LV Sogolow E: Review and meta-analysis of HIV prevention intervention research for heterosexual adult populations in the United States. JAIDS Journal of Acquired Immune Deficiency Syndromes 2002, 30:S106.

221. Noar SM: Behavioral interventions to reduce HIV-related sexual risk behavior: Review and synthesis of meta-analytic evidence. AIDS and Behavior 2008, 12(3):335-353.

222. Semaan S, Des Jarlais DC, Sogolow E, Johnson WD, Hedges LV, Ramirez G, Flores SA, Norman L, Sweat MD, Needle R: A meta-analysis of the effect of HIV prevention interventions on the sex behaviors of drug users in the United States. JAIDS Journal of Acquired Immune Deficiency Syndromes 2002, 30:573.

223. Semaan S, Kay L, Strouse D, Sogolow E, Mullen PD, Neumann MS, Flores SA, Peersman G, Johnson WD, Lipman PD: A profile of US-based trials of behavioral and social interventions for HIV risk reduction. JAIDS Journal of Acquired Immune Deficiency Syndromes 2002, 30:S30.

224. Wegbreit J, Bertozzi S, DeMaria LM, Padian NS: Effectiveness of HIV prevention strategies in resource-poor countries: tailoring the intervention to the context. Aids 2006, 20(9):1217.

225. Copenhaver MM, Johnson BT, Lee I: Behavioral HIV risk reduction among people who inject drugs: meta-analytic evidence of efficacy. Journal of Substance Abuse Treatment 2006, 31(2):163-171

226. Ksobiech K: A meta-analysis of needle sharing, lending, and borrowing behaviors of needle exchange program attenders. AIDS education and prevention 2003, 15(3):257-268.

227. Lyles D, Tien JH, McCobb DP, Zeeman ML: Pituitary Network Connectivity as a Mechanism for the Luteinising Hormone Surge. Journal of neuroendocrinology 2010, 22(12):1267-1278.

228. Meader N, Li R, Des Jarlais DC, Pilling S: Psychosocial interventions for reducing injection and sexual risk behaviour for preventing HIV in drug users. Cochrane database of systematic reviews (Online) 2010, , 1: CD007192.

229. Boulot $P$, Chabbert-Buffet N, d'Ercole C, Floriot M, Fontaine $P$, Fournier $A$, Gillet JY, Gin H, Grandperret-Vauthier S, Geudj AM: French multicentric survey of outcome of pregnancy in women with pregestational diabetes. Diabetes Care 2003, 26(11):2990.
230. Damm P, Molsted-Pedersen L: Significant decrease in congenital malformations in newborn infants of an unselected population of diabetic women. Am J Obstet Gynecol 1989, 161(5):1163-1167.

231. Pregnancy outcomes in the Diabetes Control and Complications Trial. Am J Obstet Gynecol 1996, 174(4):1343-1353.

232. Dicker D, Feldberg D, Samuel N, Yeshaya A, Karp M, Goldman JA: Spontaneous abortion in patients with insulin-dependent diabetes mellitus: the effect of preconceptional diabetic control. Am J Obstet Gynecol 1988, 158(5):1161-1164.

233. Fuhrmann K, Reiher H, Semmler K, Fischer F, Fischer M, Glockner E: Prevention of congenital malformations in infants of insulin-dependent diabetic mothers. Diabetes Care 1983, 6(3):219-223.

234. Fuhrman K, Reiher li, Semmler K, E G: The Effect of Intensified Conventional Insulin Therapy before and during Pregnancy on the Malformation Rate in Offspring of Diabetic.Mothers. Clin Endocrinol 1984, 83(2):5.

235. Galindo A, Garcia Burguillo A, Azriel S, De La Fuente P, Artal R: Outcome of fetuses in women with pregestational diabetes mellitus. Journal of perinatal medicine 2006, 34(4):323-332

236. Garcia-Patterson A, Corcoy R, Rigla M, Caballero A, Adelantado JM, Altirriba O, de Leiva A: Does preconceptional counselling in diabetic women influence perinatal outcome? Ann Ist Super Sanita 1997, 33(3):333-336.

237. Goldman JA, Dicker D, Feldberg D, Yeshaya A, Samuel N, Karp M: Pregnancy outcome in patients with insulin-dependent diabetes mellitus with preconceptional diabetic control: a comparative study. Am J Obstet Gynecol 1986, 155(2):293-297.

238. Jaffiol C, Baccara MT, Renard E, Apostol DJ, Lefebvre P, Boulot P, Daures JP, Bringer J: [Evaluation of the benefits brought by pregnancy planning in type 1 diabetes mellitus]. Bull Acad Natl Med 2000, 184(5):995-1007, discussion 1007-1008.

239. Kitzmiller JL, Gavin LA, Gin GD, Jovanovic-Peterson L, Main EK, Zigrang WD: Preconception care of diabetes. JAMA: The Journal of the American Medical Association 1991, 265(6):731.

240. McElvy SS, Miodovnik M, Rosenn B, Khoury JC, Siddiqi T, Dignan PSJ, Tsang RC: A focused preconceptional and early pregnancy program in women with type 1 diabetes reduces perinatal mortality and malformation rates to general population levels. Journal of Maternal-Fetal and Neonatal Medicine 2000, 9(1):14-20.

241. Mills JL, Knopp RH, Simpson JL, Jovanovic-Peterson L, Metzger BE, Holmes LB, Aarons JH, Brown Z, Reed GF, Bieber FR, et al: Lack of relation of increased malformation rates in infants of diabetic mothers to glycemic control during organogenesis. N Engl J Med 1988, 318(11):671-676.

242. Rosenn B, Miodovnik M, Combs CA, Khoury J, Siddiqi TA: Pre-conception management of insulin-dependent diabetes: improvement of pregnancy outcome. Obstet Gynecol 1991, 77(6):846-849.

243. Rowe BR, Rowbotham CJ, Barnett AH: Pre-conception counselling, birth weight, and congenital abnormalities in established and gestational diabetic pregnancy. Diabetes research (Edinburgh, Scotland) 1987, 6(1):33.

244. Steel JM, Johnstone FD, Hepburn DA, Smith AF: Can prepregnancy care of diabetic women reduce the risk of abnormal babies? British Medical Journal 1990, 301(6760):1070.

245. Temple RC, Aldridge VJ, Murphy HR: Prepregnancy care and pregnancy outcomes in women with type 1 diabetes. Diabetes Care 2006.

246. Willhoite MB, Bennert HW Jr, Palomaki GE, Zaremba MM, Herman WH, Williams JR, Spear NH: The impact of preconception counseling on pregnancy outcomes. The experience of the Maine Diabetes in Pregnancy Program. Diabetes Care 1993, 16(2):450-455.

247. Dunne FP, Brydon P, Smith T, Essex M, Nicholson H, Dunn J: Pre-conception diabetes care in insulin-dependent diabetes mellitus. Qjm 1999, 92(3):175.

248. Garcia Ingelmo MT, Herranz de la Morena L, Martin Vaquero P, Janez Furio M, Grande Aragon C, Pallardo Sanchez LF: [Preconceptional control in diabetic women]. Rev Clin Esp 1998, 198(2):80-84.

249. Jensen BM, Kuhl C, Molsted-Pedersen L, Saurbrey N, Fog-Pedersen J: Preconceptional treatment with insulin infusion pumps in insulindependent diabetic women with particular reference to prevention of congenital malformations. Acta Endocrinol Suppl (Copenh) 1986, 277:81-85.

250. Murphy LE, Gollenberg AL, Louis GMB, Kostyniak PJ, Sundaram R: Maternal serum preconception polychlorinated biphenyl concentrations and infant birth weight. Environmental Health Perspectives 2010, 118(2):297.

251. Heller S, Damm P, Mersebach H, Skjøth TV, Kaaja R, Hod M, Durán-García S, McCance D, Mathiesen ER: Hypoglycemia in Type 1 Diabetic Pregnancy. Diabetes Care 2010, 33(3):473. 
252. Betts T, Fox C: Proactive pre-conception counselling for women with epilepsy-is it effective? Seizure 1999, 8(6):322-327.

253. Koch R, Hanley W, Levy H, Matalon R, Rouse B, Cruz FD, Azen C, Friedman EG: A preliminary report of the collaborative study of maternal phenylketonuria in the United States and Canada. Journal of inherited metabolic disease 1990, 13(4):641-650.

254. Maillot F, Lilburn M, Baudin J, Morley DW, Lee PJ: Factors influencing outcomes in the offspring of mothers with phenylketonuria during pregnancy: the importance of variation in maternal blood phenylalanine. American Journal of Clinical Nutrition 2008, 88(3):700.

255. Germain S, Nelson-Piercy C: Lupus nephritis and renal disease in pregnancy. Lupus 2006, 15(3):148.

256. Rouse B, Azen C: Effect of high maternal blood phenylalanine on offspring congenital anomalies and developmental outcome at ages 4 and 6 years: the importance of strict dietary control preconception and throughout pregnancy. The Journal of Pediatrics 2004, 144(2):235-239.

257. Güttler F, Lou H, Andresen J, Kok K, Mikkelsen I, Nielsen KB, Nielsen JB: Cognitive development in offspring of untreated and preconceptionally treated maternal phenylketonuria. Journal of inherited metabolic disease 1990, 13(4):665-671.

258. Drogari E, Beasley M, Smith I, Lloyd JK: Timing of strict diet in relation to fetal damage in maternal phenylketonuria* $1:$ : An International Collaborative Study by the MRC/DHSS Phenylketonuria Register. The Lancet 1987, 330(8565):927-930

259. Smith I, Glossop J, Beasley M: Fetal damage due to maternal phenylketonuria: effects of dietary treatment and maternal phenylalanine concentrations around the time of conception. Journal of inherited metabolic disease 1990, 13(4):651-657.

260. Carmona F, Font J, Cervera R, Muñoz F, Cararach V, Balasch J: Obstetrical outcome of pregnancy in patients with systemic lupus erythematosus. A study of 60 cases. European Journal of Obstetrics \& Gynecology and Reproductive Biology 1999, 83(2):137-142.

261. Carmona F, Font J, Moga I, Làzaro I, Cervera R, Pac V, Balasch J: Class III-IV proliferative lupus nephritis and pregnancy: a study of 42 cases. American Journal of Reproductive Immunology 2005, 53(4):182-188.

262. Chandran V, Aggarwal A, Misra R: Active disease during pregnancy is associated with poor foetal outcome in Indian patients with systemic lupus erythematosus. Rheumatology international 2005, 26(2):152-156.

263. Imbasciati E, Tincani A, Gregorini G, Doria A, Moroni G, Cabiddu G, Marcelli D: Pregnancy in women with pre-existing lupus nephritis: predictors of fetal and maternal outcome. Nephrology Dialysis Transplantation 2009, 24(2):519.

264. Podjanee Phadungkiatwattana P, Sirivatanapa $P$, Tongsong T: Outcomes of pregnancies complicated by systemic lupus erythematosus (SLE). JOURNAL-MEDICAL ASSOCIATION OF THAILAND 2007, 90(10):1981.

265. Tiet QQ, Mausbach B: Treatments for patients with dual diagnosis: a review. Alcoholism: Clinical and Experimental Research 2007, 31(4):513-536.

266. Krishnan V, Bryant HU, MacDougald OA: Regulation of bone mass by Wnt signaling. Journal of Clinical Investigation 2006, 116(5):1202.

267. McFarlane J, Parker B, Soeken K: Abuse during pregnancy: frequency, severity, perpetrator, and risk factors of homicide. Public Health Nurs 1995, 12(5):284-289.

268. Rodríguez $\mathrm{M}$, Valentine $\mathrm{JM}$, Son JB, Muhammad M: Intimate partner violence and barriers to mental health care for ethnically diverse populations of women. Trauma, Violence, \& Abuse 2009, 10(4):358.

269. Forte T, Cohen MM, Du Mont J, Hyman I, Romans S: Psychological and physical sequelae of intimate partner violence among women with limitations in their activities of daily living. Archives of women's mental health 2005, 8(4):248-256.

270. Seth P, Raiford JL, Robinson LSS, Wingood GM, DiClemente RJ: Intimate partner violence and other partner-related factors: correlates of sexually transmissible infections and risky sexual behaviours among young adult African American women. Sexual health 2010, 7(1):25-30.

271. Salam MA, Alim MA, Noguchi T: Spousal abuse against women and its consequences on reproductive health: a study in the urban slums in Bangladesh. Maternal and Child Health Journal 2006, 10(1):83-94.

272. Jewkes RK, Dunkle K, Nduna M, Shai N: Intimate partner violence, relationship power inequity, and incidence of HIV infection in young women in South Africa: a cohort study. The Lancet 2010, 376(9734):41-48.

273. Macy RJ, Martin SL, Kupper LL, Casanueva C, Guo S: Partner Violence Among Women Before, During, and After Pregnancy: Multiple Opportunities for Intervention. Women's Health Issues 2007, 17(5):290-299.
274. Ellsberg M, Jansen HAFM, Heise L, Watts CH, Garcia-Moreno C: Intimate partner violence and women's physical and mental health in the WHO multi-country study on women's health and domestic violence: an observational study. The Lancet 2008, 371(9619):1165-1172.

275. McCauley J, Kern DE, Kolodner K, Dill L, Schroeder AF, DeChant HK, Ryden J, Bass EB, Derogatis LR: The "battering syndrome": prevalence and clinical characteristics of domestic violence in primary care internal medicine practices. Annals of internal medicine 1995, 123(10):737.

276. Stephenson R, Koenig MA, Ahmed S: Domestic violence and symptoms of gynecologic morbidity among women in North India. International Family Planning Perspectives 2006, 32(4):201-208.

277. Saltzman LE, Johnson CH, Gilbert BC, Goodwin MM: Physical abuse around the time of pregnancy: an examination of prevalence and risk factors in 16 states. Maternal and Child Health Journal 2003, 7(1):31-43.

278. Raj A, Liu R, McCleary-Sills J, Silverman JG: South Asian victims of intimate partner violence more likely than non-victims to report sexual health concerns. Journal of Immigrant Health 2005, 7(2):85-91.

279. Wupperman P, Amble P, Devine S, Zonana H, Fals-Stewart W, Easton C: Violence and Substance Use Among Female Partners of Men in Treatment for Intimate-Partner Violence. Journal of the American Academy of Psychiatry and the Law Online 2009, 37(1):75.

280. Decker MR, Seage GR, Hemenway D, Gupta J, Raj A, Silverman JG: Intimate partner violence perpetration, standard and gendered STI/HIV risk behaviour, and STI/HIV diagnosis among a clinic-based sample of men. Sexually transmitted infections 2009, 85(7):555.

281. Bauer HM, Gibson P, Hernandez M, Kent C, Klausner J, Bolan G: Intimate partner violence and high-risk sexual behaviors among female patients with sexually transmitted diseases. Sexually transmitted diseases 2002, 29(7):411.

282. Gómez AM, Speizer IS, Beauvais H: Sexual violence and reproductive health among youth in Port-au-Prince, Haiti. Journal of Adolescent Health 2009, 44(5):508-510.

283. Smedslund G, Dalsbø TK, Steiro AK, Winsvold A, Clench-Aas J: Cognitive behavioural therapy for men who physically abuse their female partner (Review). 2011.

284. Decker MR, Miller E, Kapur NA, Gupta J, Raj A, Silverman JG: Intimate partner violence and sexually transmitted disease symptoms in a national sample of married Bangladeshi women. International Journal of Gynecology \& Obstetrics 2008, 100(1):18-23.

285. Hedin LW, Janson PO: Domestic violence during pregnancy. The prevalence of physical injuries, substance use, abortions and miscarriages. Acta Obstet Gynecol Scand 2000, 79(8):625-630.

286. McFarlane J, Malecha A, Watson K, Gist J, Batten E, Hall I, Smith S: Intimate partner sexual assault against women: frequency, health consequences, and treatment outcomes. Obstetrics \& Gynecology 2005, 105(1):99.

287. Glander SS, Moore ML, Michielutte R, Parsons LH: The prevalence of domestic violence among women seeking abortion. Obstet Gynecol 1998, 91(6):1002-1006

288. Bonomi AE, Thompson RS, Anderson M, Reid RJ, Carrell D, Dimer JA, Rivara FP: Intimate partner violence and women's physical, mental, and social functioning. Am J Prev Med 2006, 30(6):458-466.

289. Beydoun HA, Al-Sahab B, Beydoun MA, Tamim H: Intimate Partner Violence as a Risk Factor for Postpartum Depression Among Canadian Women in the Maternity Experience Survey. Annals of epidemiology 2010, 20(8):575-583.

290. Hurwitz EJH, Gupta J, Liu R, Silverman JG, Raj A: Intimate partner violence associated with poor health outcomes in US South Asian women. Journal of Immigrant and Minority Health 2006, 8(3):251-261.

291. Janssen PA, Holt VL, Sugg NK, Emanuel I, Critchlow CM, Henderson AD: Intimate partner violence and adverse pregnancy outcomes: a population-based study. Am J Obstet Gynecol 2003, 188(5):1341-1347.

292. Stein MB, Kennedy C: Major depressive and post-traumatic stress disorder comorbidity in female victims of intimate partner violence. Journal of Affective Disorders 2001, 66(2-3):133-138.

293. Hegarty K, Gunn J, Chondros P, Small R: Association between depression and abuse by partners of women attending general practice: descriptive, cross sectional survey. British Medical Journal 2004, 328(7440):621.

294. Modie-Moroka T: Intimate Partner Violence and Sexually Risky Behavior in Botswana: Implications for HIV Prevention. Health Care for Women International 2009, 30(3):230-231. 
295. Pallitto CC, O'Campo P: The Relationship between Intimate Partner Violence and Unintended Pregnancy: Analysis of a National Sample from Colombia. International Family Planning Perspectives 2004, 30(4):165-174.

296. Clark CJ, Silverman J, Khalaf IA, Ra'ad BA, Al Sha'ar ZA, Al Ata AA, Batieha A: Intimate partner violence and interference with women's efforts to avoid pregnancy in Jordan. Studies in Family Planning 2008, 39(2):123-132.

297. Naimi TS, Lipscomb LE, Brewer RD, Gilbert BC: Binge drinking in the preconception period and the risk of unintended pregnancy: implications for women and their children. Pediatrics 2003, 111(5):1136.

298. Martin SL, Kilgallen B, Tsui AO, Maitra K, Singh KK, Kupper LL: Sexual behaviors and reproductive health outcomes. JAMA: The Journal of the American Medical Association 1999, 282(20):1967.

299. Coker AL, Sanderson M, Dong B: Partner violence during pregnancy and risk of adverse pregnancy outcomes. Paediatr Perinat Epidemiol 2004, 18(4):260-269.

300. Alio AP, Daley EM, Nana PN, Duan J, Salihu HM: Intimate partner violence and contraception use among women in Sub-Saharan Africa. International journal of gynaecology and obstetrics: the official organ of the International Federation of Gynaecology and Obstetrics 2009, 107(1):35.

301. Silverman JG, Decker MR, Reed E, Raj A: Intimate partner violence victimization prior to and during pregnancy among women residing in 26 US states: associations with maternal and neonatal health. American journal of obstetrics and gynecology 2006, 195(1):140-148.

302. Ruiz-Pérez I, Plazaola-Castaño J, del Río-Lozano M: Physical health consequences of intimate partner violence in Spanish women. The European Journal of Public Health 2007, 17(5):437.

303. Plichta SB, Falik M: Prevalence of violence and its implications for women's health. Women's Health Issues 2001, 11(3):244-258.

304. Ishida K, Stupp P, Melian M, Serbanescu F, Goodwin M: Exploring the associations between intimate partner violence and women's mental health: Evidence from a population-based study in Paraguay. Social Science \& Medicine 2010

305. Martin SL, Rentz ED, Chan RL, Givens J, Sanford CP, Kupper LL, Garrettson M, Macy RJ: Physical and Sexual Violence Among North Carolina Women:: Associations with Physical Health, Mental Health, and Functional Impairment. Women's Health Issues 2008, 18(2):130-140.

306. Coker AL, Smith PH, Bethea L, King MR, McKeown RE: Physical health consequences of physical and psychological intimate partner violence. Archives of family medicine 2000, 9(5):451.

307. Ellsberg M, Caldera T, Herrera A, Winkvist A, Kullgren G: Domestic violence and emotional distress among Nicaraguan women: Results from a population-based study. American Psychologist 1999, 54(1):30.

308. Åsling Monemi K, Tabassum Naved R, Persson LÅ: Violence against women and the risk of under five mortality: analysis of community based data from rural Bangladesh. Acta Paediatrica 2008, 97(2):226-232.

309. Raj A, Santana MC, La Marche A, Amaro H, Cranston K, Silverman JG: Perpetration of intimate partner violence associated with sexual risk behaviors among young adult men. American journal of public health 2006 96(10):1873

310. Dude A: Intimate partner violence and increased lifetime risk of sexually transmitted infection among women in Ukraine. Studies in Family Planning 2007, 38(2):89-100.

311. Fanslow J, Whitehead A, Silva M, Robinson E: Contraceptive use and associations with intimate partner violence among a population based sample of New Zealand women. Australian and New Zealand Journal of Obstetrics and Gynaecology 2008, 48(1):83-89.

312. Dunkle KL, Jewkes RK, Nduna M, Levin J, Jama N, Khuzwayo N, Koss MP Durvury N: Perpetration of partner violence and HIV risk behaviour among young men in the rural Eastern Cape, South Africa. Aids 2006, 20(16):2107.

313. Grisso JA, Schwarz DF, Hirschinger N, Sammel M, Brensinger C, Santanna J, Lowe RA, Anderson E, Shaw LM, Bethel CA: Violent injuries among women in an urban area. New England journal of medicine 1999, 341(25):1899-1905.

314. Chang JC, Cluss PA, Ranieri L, Hawker L, Buranosky R, Dado D, McNeil M, Scholle SH: Health care interventions for intimate partner violence: what women want. Women's health issues: official publication of the Jacobs Institute of Women's Health 2005, 15(1):21.

315. Riddell T, Ford-Gilboe M, Leipert B: Strategies Used by Rural Women to Stop, Avoid, or Escape From Intimate Partner Violence. Health Care for Women International 2009, 30(1):134-159.

316. Scott MC, Easton CJ: Racial differences in treatment effect among men in a substance abuse and domestic violence program. Am J Drug Alcohol Abuse 2010, 36(6):357-362.
317. Hirani SS, Karmaliani R, McFarlane J, Asad N, Madhani F: testing a community derived intervention to promote women's health: preliminary results of a 3-arm randomized controlled trial in Karachi, Pakistan. 2010.

318. Babcock JC, Green CE, Robie C: Does batterers' treatment work? A metaanalytic review of domestic violence treatment. Clinical Psychology Review 2004, 23(8):1023-1053.

319. O'Leary KD, Heyman RE, Neidig PH: Treatment of wife abuse: A comparison of gender-specific and conjoint approaches. Behavior Therapy 1999, 30(3):475-505.

320. Markman HJ, Renick MJ, Floyd FJ, Stanley SM, Clements M: Preventing marital distress through communication and conflict management training: A 4-and 5-year follow-up. Journal of Consulting and Clinical Psychology 1993, 61(1):70.

321. Simpson LE, Atkins DC, Gattis KS, Christensen A: Low-level relationship aggression and couple therapy outcomes. Journal of Family Psychology 2008, 22(1):102.

322. Stith SM, Rosen $\mathrm{H}$, McCollum EE, Thomsen $\mathrm{CJ}$ : treating intimate partner violence within intact couple relationships: outcomes of multi couple versus individual couple therapy. Journal of Marital and Family Therapy 2004, 30(3):305-318.

323. Labriola M, Rempel M, Davis RC: Testing the effectiveness of batterer programs and judicial monitoring. Final report (National Institute of Justice, Washington, DC) 2005.

324. Davis RC, Taylor BG, Maxwell CD, Victim Services R: Does Batterer Treatment Reduce Violence? A Randomized Experiment in BrooklynExecutive Summary Included. 2000.

325. Feder L, Forde DR: Test of the efficacy of court Mandated counseling for domestic violence offenders: The Broward Experiment, Executive Summary. Washington, DC: National Institute of Justice 2000.

326. Dunford FW: The San Diego Navy Experiment: An assessment of interventions for men who assault their wives. Journal of Consulting and Clinical Psychology 2000, 68(3):468.

327. Saunders DG: Feminist-cognitive-behavioral and process-psychodynamic treatments for men who batter: Interaction of abuser traits and treatment models. Violence and victims 1996, 11(4):393-414.

328. Rychtarik RG, McGillicuddy NB: Coping skills training and 12-step facilitation for women whose partner has alcoholism: effects on depression, the partner's drinking, and partner physical violence. Journal of Consulting and Clinical Psychology 2005, 73(2):249.

329. Ray JG, O'Brien TE, Chan WS: Preconception care and the risk of congenital anomalies in the offspring of women with diabetes mellitus: a meta analysis. QJM 2001, 94(8):435.

330. Wahabi HA, Alzeidan RA, Bawazeer GA, Alansari LA, Esmaeil SA: Preconception care for diabetic women for improving maternal and fetal outcomes: a systematic review and meta-analysis. BMC pregnancy and childbirth 2010, 10(1):63.

331. Gavin AR, Chae DH, Mustillo S, Kiefe Cl: Prepregnancy depressive mood and preterm birth in black and white women: Findings from the CARDIA study. Journal of Women's Health 2009, 18(6):803.

332. Jonsson U, Bohman $H$, Hjern $A$, von Knorring $L$, Paaren $A$, Olsson $G$, von Knorring AL: Intimate relationships and childbearing after adolescent depression: a population-based 15 year follow-up study. Social Psychiatry and Psychiatric Epidemiology 2010, 1-11.

333. Silverman ME, Loudon $\mathrm{H}$ : Antenatal reports of pre-pregnancy abuse is associated with symptoms of depression in the postpartum period. Archives of Women's Mental Health 2010, 1-5.

334. Harlow BL, Vitonis AF, Sparen P, Cnattingius S, Joffe H, Hultman CM: Incidence of hospitalization for postpartum psychotic and bipolar episodes in women with and without prior prepregnancy or prenatal psychiatric hospitalizations. Archives of General Psychiatry 2007, 64(1):42.

335. Goodwin MM, Gazmararian JA, Johnson CH, Gilbert BC, Saltzman LE: Pregnancy intendedness and physical abuse around the time of pregnancy: findings from the pregnancy risk assessment monitoring system, 1996-1997. PRAMS Working Group. Pregnancy Risk Assessment Monitoring System. Matern Child Health J 2000, 4(2):85-92.

doi:10.1186/1742-4755-11-S3-S7

Cite this article as: Lassi et al:: Preconception care: delivery strategies and packages for care. Reproductive Health 2014 11(Suppl 3):S7. 